\title{
Exogenous Trehalose Induces Defenses in Wheat Before and During a Biotic Stress Caused by Powdery Mildew
}

\author{
Christine Tayeh, Béatrice Randoux, Dorothée Vincent, Natacha Bourdon, and Philippe Reignault
}

First, second, fourth, and fifth authors: Université du Littoral Côte d'Opale, Unité de Chimie Environnementale et Interactions sur le Vivant, GIS PhyNoPi, C.S. 80699, F-62228, Calais cedex, France; All authors: Université Lille Nord de France, F-59000 Lille, France; and third author: Université du Littoral Côte d'Opale, Laboratoire d'Océanologie et de Géosciences, F-62930 Wimereux, France, and CNRS UMR 8187, F-62930, France.

Accepted for publication 12 September 2013.

\begin{abstract}
Tayeh, C., Randoux, B., Vincent, D., Bourdon, N., and Reignault, P. 2014. Exogenous trehalose induces defenses in wheat before and during a biotic stress caused by powdery mildew. Phytopathology 104:293-305.

Powdery mildew would be one of the most damaging wheat diseases without the extensive use of conventional fungicides. Some of the alternative control strategies currently emerging are based on the use of resistance inducers. The disacharride trehalose (TR) is classically described as an inducer of defenses in plants to abiotic stress. In this work, the elicitor or priming effect of TR was investigated in wheat both before and during a compatible wheat-powdery mildew interaction through molecular, bio-

Moreover, lipid metabolism was shown to be altered by TR spraying via the upregulation of lipoxygenase (lox) and lipid-transfer protein (ltp)encoding gene expression. On the other hand, the protection conferred by TR to wheat against powdery mildew is associated with the induction of two specific defense markers. Indeed, in infectious conditions following TR spraying, upregulations of chi4 precursor and lox gene expression as well as an induction of the LOX activity were observed. These results are also discussed with regard to the impact of TR on the fungal infectious process, which was shown to be stopped at the appressorial germ tube stage. Our findings strongly suggest that TR is a true inducer of wheat defense and resistance, at least toward powdery mildew.
\end{abstract} chemical, and cytological approaches. In noninoculated conditions, TR elicited the expression of genes encoding chitinase (chi, chil, and chi4 precursor), pathogenesis-related protein 1, as well as oxalate oxidase (oxo).
Additional keywords: Blumeria graminis f. sp. tritici, compatible interaction, defense reaction.
Sugars such as glucose, fructose, and sucrose are involved in many metabolic and signaling pathways in plants. Among sugars, trehalose (TR) is emerging as an important molecule involved in stress response in many organisms (15). TR is a nonreducing $\alpha, \alpha-$ 1,1 -linked glucose disaccharide used both as an energy source and a storage form of more reactive glucose in lower organisms (17). Its ability to establish hydrogen bonds with membranes and macromolecules under dehydration conditions also makes it also a suitable osmoprotectant (15). Even though higher plants synthesize TR, except for a few desiccation-tolerant species, they only contain trace amounts of TR, arguing against its involvement both as an energy source in standard conditions and as an osmoprotectant otherwise. The general consensus is that TR and its phosphorylated form, TR-6-phosphate (T6P), have a signaling function in plants $(15,43)$. T6P is emerging as an important regulator of plant growth, development, and senescence (65). In addition, stress tolerance is higher in mutant and transgenic plants that constitutively accumulate high levels of TR compared with wild ones $(11,16,18)$, suggesting that a high TR content can promote stress resistance in plants. Moreover, TR is also involved in plant response to biotic stresses. Indeed, it was found to accumulate in Arabidopsis thaliana roots during a nematode infection (22). The expression of a putative T6P synthase/phosphatase 11 (TPS11) gene increased in A. thaliana plants infected with Tobacco mosaic virus (19). Singh et al. (55) showed that the TPS11 gene mediates resistance in A. thaliana against the green peach

Corresponding author: P. Reignault;

E-mail address: philippe.reignault@univ-littoral.fr

http://dx.doi.org/10.1094/PHYTO-07-13-0191-R

(C) 2014 The American Phytopathological Society aphid through the expression of the phytoalexin-deficient 4 gene. In contrast to wild-type plants, neither TR accumulation nor resistance against green peach aphid were observed in tps 11 knockout plants. Resistance was restored by an exogenous TR application, suggesting that TR is an essential signal in the defense process (55). Signaling sugars may actually contribute to immune responses against pathogens and probably function as priming molecules leading to pathogen-associated molecular pattern (PAMP)-triggered immunity and effector-triggered immunity in plants (39).

Indeed, applications of inducers that mimic natural signaling compounds have been shown to be effective against a broad spectrum of pathogens in various plants. Thus, elicitors or resistance inducers active at low doses could be used to reinforce plant inherent defenses, especially in crop susceptible cultivars. These molecules could contribute to reducing the negative impact of conventional fungicides on both environment and human health by taking part in the traditional programs of crop protection.

In the compatible wheat-powdery mildew interaction, partial induced resistance has been obtained with different elicitors and resistance inducers such as TR but also salicylic acid (SA), heptanoyl SA (HSA), Iodus40, Milsana, and nonacetylated and acetylated oligogalacturonides $(41,46,47,49,50)$. Exogenous applications of TR partially protect wheat against powdery mildew (Blumeria graminis f. sp. tritici). Sprayings of wheat leaves with TR solution conferred a 50 to $60 \%$ protection level against powdery mildew $(41,49,50)$. Moreover, TR did not inhibit conidial germination or appressoria differentiation in vitro $(49,50)$, suggesting that the conferred protection is the result of induced defense responses.

The present study aimed at identifying defense markers specifically induced by TR, and then at investigating the modification of 
their expression in relation to alterations of specific stages of the powdery mildew infectious process on wheat. The gene expression we investigated here has been previously shown to be involved in wheat defense reactions against several pathogens. The chitinase (chi) gene (AY437443) expression was shown to be strongly induced in a wheat cultivar susceptible to Septoria tritici (Zymoseptoria tritici) (54) and the expressions of chil and chi4 precursor genes (AB029934 and AF112966) were upregulated in response to methyl-jasmonate treatment and potentiated upon Tilletia laevis infection (36). The pathogenesis-related 1 (PR1) gene (HQ 848391) was isolated from wheat leaves infected by Puccinia triticina (8). The gstF gene (AF387085) was chosen regarding the phi glutathione S-transferase (GST) that it encodes (cdd 48602), the latter being involved in cellular detoxification of products of oxidative stress as well as in transport of flavonoid pigments. Transcripts of oxalate oxidase (M21962), a reactive oxygen species (ROS)-generating enzyme, accumulated in wheat resistant to Hessian fly attack 24 and $48 \mathrm{~h}$ after infection (33). A lipoxygenase (lox)-encoding gene (U32428) was chosen regarding its early and high responsiveness to several elicitors in wheat tissues and, more specifically, its involvement in defense reactions against $B$. graminis f. sp. tritici (21). The wheat lipid-transfer protein (ltp)-encoding gene $3 F 1$ (EF432573) encodes an LTP protein that exhibited a broad-spectrum antifungal activity in vitro. Moreover, transgenic tobacco expressing the ltp $3 F 1$ gene showed fungal resistance to Bipolaris oryzae, Cylindrocladium scoparium, and Alternaria sp. (28). The phosphoinositide-specific phospholipase C (PI-PLC2) gene (HM754653) identified by Khalil et al. (27) in wheat encodes PI-PLC. The activity and localization of PI-PLC enzymes have also been shown to regulate membrane trafficking (60) and to play a role in signaling involved in disease resistance in tomato (64). In a first step, the ability of TR to trigger these selected defense-related gene expressions in noninoculated wheat plantlets was tested in order to investigate any eliciting activity. Furthermore, in infectious conditions, the potentiation of expression of selected defense-related genes after TR treatment was also followed in a time-course experiment by real-time reverse-transcription quantitative polymerase chain reaction (RT-qPCR), as well as corresponding enzymatic assays. Finally, direct infiltration of a TR solution in wheat leaves was also performed to assess per se biological activities of such a hydrophilic molecule independently of its potentially weak ability to penetrate the hydrophobic plant cuticle.

\section{MATERIALS AND METHODS}

Unless otherwise specified, the different chemicals used in this study were purchased from Sigma (Saint-Quentin Fallavier, France).

Plant culture and pathogen maintenance. Caryopses of wheat (Triticum aestivum) 'Orvantis', a variety without any known re- sistance gene to any Blumeria graminis f. sp. tritici race and susceptible to powdery mildew, were sown in plastic trays (24 plantlets in a 30-by-12-cm tray). After germination, plantlets were grown in compost for 10 days to complete expansion of the first primary leaf in a growth chamber (12-h photoperiod, light intensity $250 \mu \mathrm{mol} \mathrm{m} \mathrm{m}^{-2} \mathrm{~s}^{-1}$, day temperature $18^{\circ} \mathrm{C}$, night temperature $12^{\circ} \mathrm{C}, 70 \%$ relative humidity).

The MPEBgtl isolate used in this study was inoculated and maintained on Orvantis plants in a separate room. Heavily sporulating leaves were shaken above 11-day-old plantlets and inoculated plants were left in the room until new, fully sporulating leaves were obtained, usually within 8 to 10 days.

Plant treatment and inoculation. Two distinct methods were used to apply TR treatments. (i) TR was sprayed in noninfectious and infectious conditions. TR solution (15 g/liter; $44 \mathrm{mM}$ ) was freshly prepared before use in distillated water supplemented with $0.025 \%$ (vol/vol) Citowett (BASF, Levallois-Perret, France), a wetting agent, whereas the corresponding control consisted of distilled water supplemented with Citowett. Treatment with TR or water consisted of a single spraying on 10-day-old plantlets. At $48 \mathrm{~h}$ after treatment, inoculation-challenged plantlets were sprayed with $B$. graminis f. sp. tritici conidia suspended in Fluorinert FC43 (3M, Cergy-Pontoise, France). The inoculum concentration was adjusted to $5 \times 10^{5}$ spores/ml. (ii) Infiltration of TR (15 g/liter; $44 \mathrm{mM}$ ) inside 10-day-old leaf tissues was undergone with a hypodermic syringe without a needle. Infiltrated areas were delineated with a marker pen. Control plantlets were infiltrated with distilled water.

RNA extraction and quantification of gene expression with real-time RT-qPCR. The expression levels of a set of nine genes were monitored by real-time RT-qPCR. The gene set included genes encoding for PR proteins such as PR1 and chitinases; a hydrogen peroxide $\left(\mathrm{H}_{2} \mathrm{O}_{2}\right)$-producing enzyme; oxalate oxidase (also designated as PR8), an ROS-detoxifying enzyme; class phi GST (GSTF); and some genes involved in the lipid metabolism and oxylipin pathway such as phospholipase C2-encoding gene, $l t p$ - and lox-encoding genes. Primers' sequences and accession numbers are mentioned in Table 1. A couple of reference genes were selected in each experiment among three tested genes, including the elongation factor 1 gene $(e f l \alpha)$, the $\beta$-tubulin gene $(t u b)$, and the actin gene (act). The tub and act genes were used in both infectious and noninfectious spraying experiments because neither treatments nor inoculation affected their expression level stability over the time-course experiment. The efl $\alpha$ and tub genes were used in the infiltration experiments because infiltration had an effect on the stability of act expression. Primers were designed using the Primer Express program and were tested for secondary structure using the NetPrimer program. To ensure correct normalization in real-time PCR, amplification efficiencies were checked for similarities.

TABLE 1. Primers used in the quantitative real-time reverse-transcription polymerase chain reaction studies

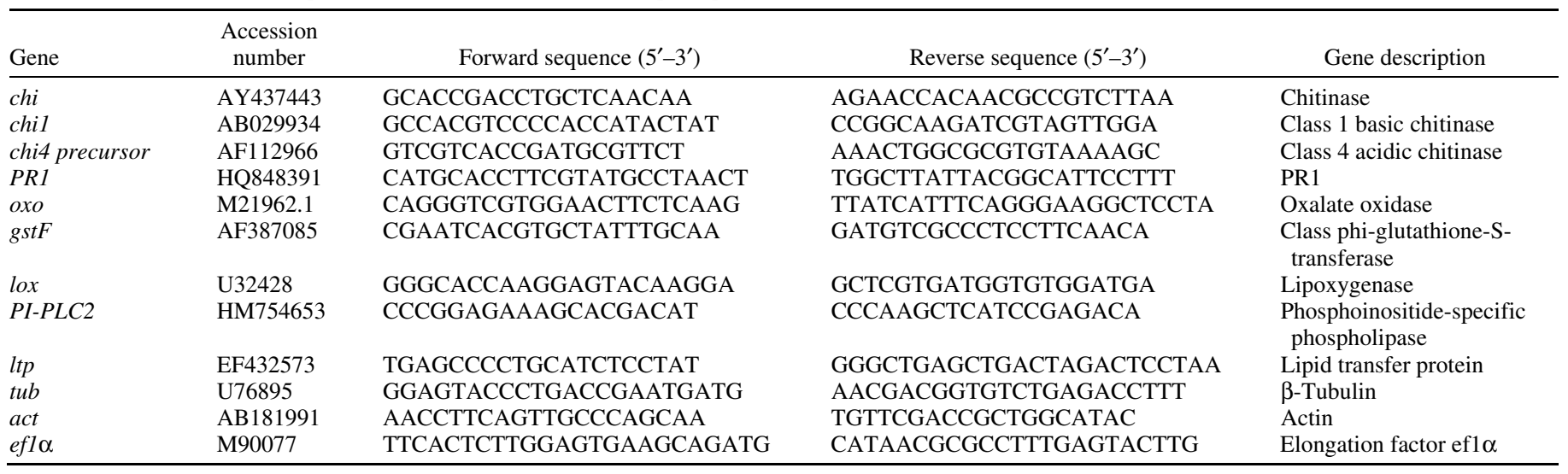


Sprayed leaves were sampled every $3 \mathrm{~h}$ the first $24 \mathrm{~h}$ post spraying (hps). Because inoculation with $B$. graminis f. sp. tritici was done 48 hps, samples were also collected every $3 \mathrm{~h}$ the first day after inoculation, then every $24 \mathrm{~h}$ after inoculation (hai) for a total period of 4 days. The same corresponding sampling profile was also conducted in noninfectious conditions. For the infiltration experiment, infiltrated leaves were sampled every $3 \mathrm{~h}$ in the first $24 \mathrm{~h}$ post infiltration (hpi), then every $24 \mathrm{~h}$ over a total period of 5 days. Samples were immediately frozen at $-80^{\circ} \mathrm{C}$. Each sample consisted of three half leaves from which the RNA was extracted using RNeasy Plant Mini Kit (Qiagen, The Netherlands), with some modifications of the protocol. Genomic DNA contaminating the samples was removed by treatment with DNase using RNase-Free DNase Set (Qiagen), leading to highquality RNA samples. Reverse transcription of $2 \mu \mathrm{g}$ of total RNA was carried out using the High Capacity cDNA Reverse Transcription Kit (Applied Biosystems, the Netherlands) according to the manufacturer's protocol. Thereafter, real-time qPCR was performed using the ABI Prism 7300 detection system (Applied Biosystems). Expression ratios for each cDNA were calculated for each time point relative to control leaves at the same time. The expression level of the gene of interest in control leaves used for the relative expressions was considered to be 1 . Each sample was assayed three times in each independent experiment.

Enzyme activities. Enzyme activities were monitored during a time-course experiment. Sprayed leaves were sampled every $6 \mathrm{~h}$ the first 24 hps. Because inoculation with B. graminis f. sp. tritici was done $48 \mathrm{hps}$, samples were also collected every $6 \mathrm{~h}$ the first day after inoculation, then every 24 hai over a total period of 4 days. The same corresponding sampling profile was also conducted in noninfectious conditions. For the infiltration experiment, infiltrated leaves were sampled every $6 \mathrm{~h}$ the first $24 \mathrm{hpi}$, then every $24 \mathrm{~h}$ on a total period of 5 days. Each sample consisted of a part of the first leaf collected from three different wheat plantlets. Total protein concentrations were measured using the method of Lowry et al. (35) and the standard curve was established using bovine serum albumin.

OXO (EC 1.2.3.4) activity was assayed according to the procedure of Sugiura et al. (57) and modified by Randoux et al. (47). LOX (EC 1.13.11.12) activity was measured according to Todd et al. (62) and Avdiushko et al. (2), with slight modifications made by Randoux et al. (47), and the GST (EC 2.5.1.13) assay was performed as described by Riechers et al. (51), with slight modifications according to El Chartouni et al. (14). The chitinase (EC 3.2.1.14) assay was carried out as described by Wirth and Wolf (66), with slight modifications according to Magnin-Robert et al. (37). For this assay, CM-chitin-RBV solution was purchased from Loewe Biochemica (Sauerlach, Germany).

Microscopy. For B. graminis f. sp. tritici detection, three leaves were randomly harvested at $3,6,9,12,15,18,21,24,48,72$, and 96 hai with $B$. graminis f. sp. tritici; cleared with a mixture of ethanol/acetic acid (3:1, vol/vol); and stored in lactoglycerol (lactic acid/glycerol/water, $1: 1: 1$, vol/vol/vol). Conidia were stained with $0.1 \%$ trypan blue solution. Light microscopy for B. graminis $\mathrm{f}$. sp. tritici detection using this method allowed us to differentiate eight classes of events: ungerminated conidia, conidia with a primary germ tube (PGT), conidia with both PGT and appressorial germ tube (AGT), conidia with a long AGT without any penetration peg, conidia with a long AGT with a penetration peg, conidial AGT leading to haustorial body, conidia with fully formed haustorium, and fungal colonies.

Statistical analyses. For gene expression assays, two independent experiments with three technical repetitions were carried out over the studied period. Because similar results were achieved, results obtained during one experiment will be presented thereafter. Statistical evaluations of the relative expression level of the target genes was evaluated in TR-treated material compared with the corresponding control and normalized to the appropriate reference gene expression level. The analyses were performed using the relative expression software tool REST as described by Pfaffl et al. (45). Significant differences were tested at 95\% $(P<$ $0.05)$ unless specifically mentioned.

For biochemical and microscopic assays, three independent repetitions were carried out and each repetition included three replicates $(\times 3)$. An analysis of variance was applied to the data set after testing for normal distribution (Shapiro Wilk, $n=9$ ). Variance was stabilized by appropriate logarithmic transformation when necessary. A post hoc Tukey test permitted us to assess whether any differences appeared between water-treated and TRtreated leaves. For microscopic assays, logarithmic linear regression analysis followed by an analysis of covariance (ANCOVA) was carried out to assess significant effect of TR on conidial classes. All data were analyzed using STATGRAPHICS Centurion XVI (Sigma Plus, Levallois-Perret, France).

Correspondence analysis (CA) was applied to the data set of wheat leaves (two treatments $\times$ nine gene matrices). Microscopic events consisting of different $B$. graminis f. sp. tritici infectious structures during the time-course experiment were plotted as supplementary observations on the I-II plan of the CA. This permitted us to assess the potential links between observations and gene expression.

\section{RESULTS}

For a meaningful biological approach, significantly differentially expressed transcripts were reported according to a strict selection criterion; namely, a $\geq 2$.0-fold change threshold. Gene expression was normalized to tub and act gene expression in sprayed leaves and to $t u b$ and $e f l \alpha$ gene expression in infiltrated ones.

Expression profiles of nine defense-related genes upon TR spraying in noninfectious conditions. The relative expression of the nine genes examined over the time-course experiment in TRsprayed wheat leaves compared with $\mathrm{H}_{2} \mathrm{O}$-sprayed ones (referred as controls hereafter) is shown in Table 2. Thus, the possible stress generated upon the spraying procedure per se is taken into account because it would be recorded in such control leaves.

Spraying of wheat leaves with TR induces several upregulations of chitinases and PR1-encoding genes at diverse points of the time-course experiment. A first significant upregulation of chi gene expression was recorded and resulted in a 3.4-fold increase at $18 \mathrm{hps}$ in TR-sprayed wheat leaves compared with control plantlets. It was followed by a second and third induction with 2.3- and 5.7-fold increases at 66 and $69 \mathrm{hps}$, respectively. TR spraying also significantly induced the chil gene expression at four different points over the time course; increases of 3.1 to 6.1 compared with controls were recorded at 9, 18, 21, and $66 \mathrm{hps}$. This observation also holds for the chi4 precursor gene because a profile similar to that of the chil gene was observed and gene expression ranged from 3.2- to 5.2-fold increases. Impact of TR spraying on enzymatic level resulted in a significant $96.6 \%$ increase of the total chitinase activity at $72 \mathrm{hps}$ compared with the control (Fig. 1A).

PR1-encoding transcripts accumulated in TR-sprayed wheat leaves by a 5.0 -fold increase at $9 \mathrm{hps}$ compared with controls. Additional stronger and longer inductions of $P R l$ gene expression were also recorded at 18 to 21 and 66 to $69 \mathrm{hps}$, with 19.3- to 6.8fold and 9.7- to 10-fold increases, respectively.

The expression of lox and ltp genes but not of PI-PLC2 is upregulated by TR spraying. Several significant upregulations of the lox gene expression were induced upon wheat sprayings with TR: 3.9-, 2.1-, 4.6-, 10.5-, 3.5-, and 4.0-fold increases were recorded at 12, 21, 51, 57, 66, and $120 \mathrm{hps,} \mathrm{respectively.} \mathrm{At} \mathrm{the}$ enzymatic level, wheat treatment with TR induced a $75.6 \%$ increase of the LOX activity at 66 hps (Fig. 1B). 
TR-spraying also significantly induced a 3.2-fold increase of ltp gene expression compared with the control at 6 hps. Two other significant inductions were observed: $2.2-$ and 2.0-fold increases at 57 and $72 \mathrm{hps}$, respectively.

For the PI-PLC2 gene, expression increase never exceeded a factor 2 over the whole time-course experiment.

TR induces upregulation of an ROS-generating oxo gene but not of an ROS-eliminating $g$ stF gene. A first significant upregulation of the oxo gene was observed at $18 \mathrm{hps}$ in TR-sprayed wheat leaves with a 7.2-fold increase compared with the control, followed by a slight 2.0 -fold increase at $69 \mathrm{hps}$. However, no stimulation of the OXO enzymatic activity was recorded over the whole time-course experiment (data not shown).

Neither the GSTF-encoding gene expression (Table 2) nor the corresponding GST activity was induced upon TR treatment of wheat leaves (data not shown).

The infectious process of $B$. graminis f. sp. tritici in TRsprayed wheat leaves is impaired at the AGT stage. The time course of the infectious process of $B$. graminis f. sp. tritici on wheat leaves was assessed in both $\mathrm{H}_{2} \mathrm{O}$ - and TR-sprayed leaves. ANCOVA revealed a significant difference between TR-sprayed and $\mathrm{H}_{2} \mathrm{O}$-sprayed leaves $(P \leq 0.05)$, highlighting the fact that the conidia with PGT class is observed longer (6 to 18 hai) compared with the control (Fig. 2A). This observation also holds for TRtreated leaves, where conidia with both PGT and AGT class lasted longer (18 to 96 hai) when compared with control (Fig. 2B). As a consequence, TR-treated leaves presented less-differentiated haustoria $(39.7 \%)$ compared with $\mathrm{H}_{2} \mathrm{O}$-sprayed leaves $(70.7 \%)$ at 96 hai (data not shown).

Expression profiles of defense-related genes in infectious conditions upon TR spraying. The expression profiles of genes in leaves sprayed with TR or $\mathrm{H}_{2} \mathrm{O}$ and subsequently inoculated with $B$. graminis f. sp. tritici are represented in Figures 3 and 4. Transcript levels for control $\mathrm{H}_{2} \mathrm{O}$-sprayed noninfectious samples at each time point were considered as basal levels during expression analysis and, therefore, the corresponding transcript levels were attributed the unit value (1.00). The profile expression of selected genes in both $\mathrm{H}_{2} \mathrm{O}$-sprayed and TR-sprayed in-

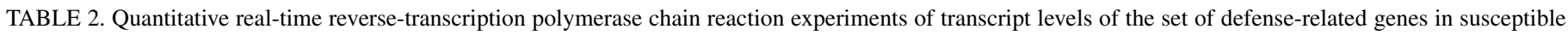
wheat 'Orvantis' post trehalose (TR) spraying in noninfectious context ${ }^{\mathrm{y}}$

\begin{tabular}{|c|c|c|c|c|c|c|c|c|c|}
\hline $\mathrm{hps}^{\mathrm{Z}}$ & chi & chil & chi4 precursor & PR1 & $\operatorname{lox}$ & oxo & gstF & $P I-P L C 2$ & ltp \\
\hline 0 & 1 & 1 & 1 & 1 & 1 & 1 & 1 & 1 & 1 \\
\hline 3 & $0.8 \mathrm{NS}$ & $1.5 \mathrm{NS}$ & $1.1 \mathrm{NS}$ & $1.1 \mathrm{NS}$ & $0.2 \mathrm{~A}$ & $1.4 \mathrm{NS}$ & $0.7 \mathrm{~A}$ & $0.7 \mathrm{~A}$ & $0.6 \mathrm{~A}$ \\
\hline 6 & $0.7 \mathrm{NS}$ & $1.0 \mathrm{NS}$ & $1.1 \mathrm{NS}$ & $0.2 \mathrm{~A}$ & $1.1 \mathrm{NS}$ & $1.1 \mathrm{NS}$ & $1.0 \mathrm{NS}$ & $1.2 \mathrm{NS}$ & $3.2 \mathrm{~B}$ \\
\hline 9 & $1.5 \mathrm{~A}$ & $5.2 \mathrm{~A}$ & $4.1 \mathrm{~A}$ & $5.0 \mathrm{~A}$ & $0.5 \mathrm{NS}$ & $1.5 \mathrm{~A}$ & $1.3 \mathrm{~A}$ & $0.8 \mathrm{NS}$ & $1.1 \mathrm{~A}$ \\
\hline 12 & $0.5 \mathrm{NS}$ & $0.5 \mathrm{NS}$ & $0.7 \mathrm{NS}$ & $0.1 \mathrm{NS}$ & $3.9 \mathrm{~A}$ & $0.9 \mathrm{NS}$ & $0.8 \mathrm{NS}$ & $1.7 \mathrm{~A}$ & $1.4 \mathrm{~A}$ \\
\hline 15 & $1.1 \mathrm{NS}$ & $0.8 \mathrm{NS}$ & $1.1 \mathrm{NS}$ & $0.8 \mathrm{NS}$ & $2.6 \mathrm{NS}$ & $1.3 \mathrm{~A}$ & $0.8 \mathrm{NS}$ & $1.1 \mathrm{~A}$ & $1.5 \mathrm{NS}$ \\
\hline 18 & $3.4 \mathrm{~A}$ & $6.1 \mathrm{~A}$ & $5.2 \mathrm{~A}$ & $19.3 \mathrm{~A}$ & $1.2 \mathrm{~A}$ & $7.2 \mathrm{~A}$ & $1.5 \mathrm{~A}$ & $1.3 \mathrm{~A}$ & $1.6 \mathrm{~A}$ \\
\hline 21 & $1.3 \mathrm{~A}$ & $3.1 \mathrm{~A}$ & $3.2 \mathrm{~A}$ & $6.8 \mathrm{~A}$ & $2.1 \mathrm{~A}$ & $1.9 \mathrm{~A}$ & $1.3 \mathrm{~A}$ & $1.0 \mathrm{NS}$ & $1.3 \mathrm{~A}$ \\
\hline 24 & $0.6 \mathrm{~A}$ & $1.0 \mathrm{NS}$ & $0.7 \mathrm{~A}$ & $0.9 \mathrm{NS}$ & $0.9 \mathrm{~A}$ & $0.5 \mathrm{~A}$ & $1.0 \mathrm{~A}$ & $1.1 \mathrm{NS}$ & $0.6 \mathrm{~A}$ \\
\hline 48 & $0.9 \mathrm{NS}$ & $0.6 \mathrm{NS}$ & $0.4 \mathrm{~A}$ & $0.1 \mathrm{NS}$ & $0.7 \mathrm{~A}$ & $0.6 \mathrm{~A}$ & $0.9 \mathrm{~A}$ & $1.5 \mathrm{NS}$ & $1.5 \mathrm{~A}$ \\
\hline 51 & $0.3 \mathrm{~A}$ & $0.2 \mathrm{NS}$ & $0.5 \mathrm{NS}$ & $0.0 \mathrm{NS}$ & $4.6 \mathrm{~A}$ & $0.3 \mathrm{NS}$ & $0.5 \mathrm{NS}$ & $1.0 \mathrm{NS}$ & $0.4 \mathrm{NS}$ \\
\hline 54 & $0.3 \mathrm{NS}$ & $0.4 \mathrm{~A}$ & $0.6 \mathrm{~A}$ & $0.1 \mathrm{NS}$ & $0.2 \mathrm{~A}$ & $0.4 \mathrm{~A}$ & $0.8 \mathrm{NS}$ & $0.9 \mathrm{NS}$ & $1.7 \mathrm{NS}$ \\
\hline 57 & $0.6 \mathrm{NS}$ & $0.7 \mathrm{NS}$ & $0.8 \mathrm{~A}$ & $0.1 \mathrm{~A}$ & $10.5 \mathrm{~A}$ & $0.4 \mathrm{~A}$ & $0.9 \mathrm{~A}$ & $1.2 \mathrm{NS}$ & $2.2 \mathrm{~A}$ \\
\hline 60 & $0.9 \mathrm{NS}$ & $1.4 \mathrm{~A}$ & $1 \mathrm{NS}$ & $0.8 \mathrm{NS}$ & $0.4 \mathrm{NS}$ & $1.2 \mathrm{NS}$ & $0.9 \mathrm{NS}$ & $0.6 \mathrm{NS}$ & $1.0 \mathrm{NS}$ \\
\hline 63 & $0.9 \mathrm{NS}$ & $0.7 \mathrm{~A}$ & $1 \mathrm{NS}$ & $0.9 \mathrm{NS}$ & $0.5 \mathrm{NS}$ & $1.3 \mathrm{NS}$ & $1 \mathrm{NS}$ & $0.7 \mathrm{NS}$ & $0.6 \mathrm{NS}$ \\
\hline 66 & $2.3 \mathrm{~A}$ & $5.6 \mathrm{~A}$ & $4.4 \mathrm{~A}$ & $9.7 \mathrm{~A}$ & $3.5 \mathrm{~A}$ & $1.4 \mathrm{~A}$ & $1.4 \mathrm{~A}$ & $1.6 \mathrm{~A}$ & $0.9 \mathrm{NS}$ \\
\hline 69 & $5.7 \mathrm{~A}$ & 4.7 NS & $2 \mathrm{NS}$ & $10.0 \mathrm{~A}$ & $0.7 \mathrm{~A}$ & $2.0 \mathrm{~A}$ & $1.3 \mathrm{~A}$ & $0.9 \mathrm{NS}$ & $0.6 \mathrm{NS}$ \\
\hline 72 & $0.3 \mathrm{~A}$ & $0.1 \mathrm{NS}$ & $0.5 \mathrm{NS}$ & $0.1 \mathrm{NS}$ & $1.4 \mathrm{NS}$ & $0.2 \mathrm{NS}$ & $0.6 \mathrm{~A}$ & $1.7 \mathrm{~A}$ & $2.0 \mathrm{~A}$ \\
\hline 96 & $0.7 \mathrm{NS}$ & $0.9 \mathrm{NS}$ & $1.9 \mathrm{~A}$ & $1.8 \mathrm{~A}$ & $0.2 \mathrm{~A}$ & $0.5 \mathrm{NS}$ & $1.1 \mathrm{NS}$ & $1.2 \mathrm{NS}$ & $0.9 \mathrm{~A}$ \\
\hline 120 & $0.4 \mathrm{~A}$ & $0.4 \mathrm{NS}$ & $1.1 \mathrm{NS}$ & $0.3 \mathrm{~A}$ & $4.0 \mathrm{~A}$ & $0.5 \mathrm{NS}$ & $0.9 \mathrm{NS}$ & $1.1 \mathrm{~A}$ & $0.7 \mathrm{~A}$ \\
\hline 144 & $0.9 \mathrm{NS}$ & $1.2 \mathrm{NS}$ & $1.1 \mathrm{NS}$ & $2.5 \mathrm{NS}$ & $2.4 \mathrm{NS}$ & $0.9 \mathrm{~A}$ & $1.0 \mathrm{NS}$ & $0.8 \mathrm{~A}$ & $0.8 \mathrm{~A}$ \\
\hline
\end{tabular}

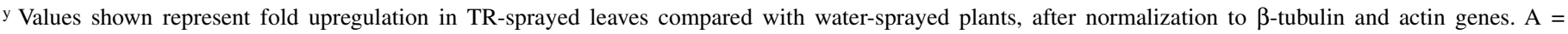
significant change, $\mathrm{NS}=$ nonsignificant change, and $\mathrm{B}=$ significant with $P=0.052$.

${ }^{\mathrm{z}}$ Hours post spraying.
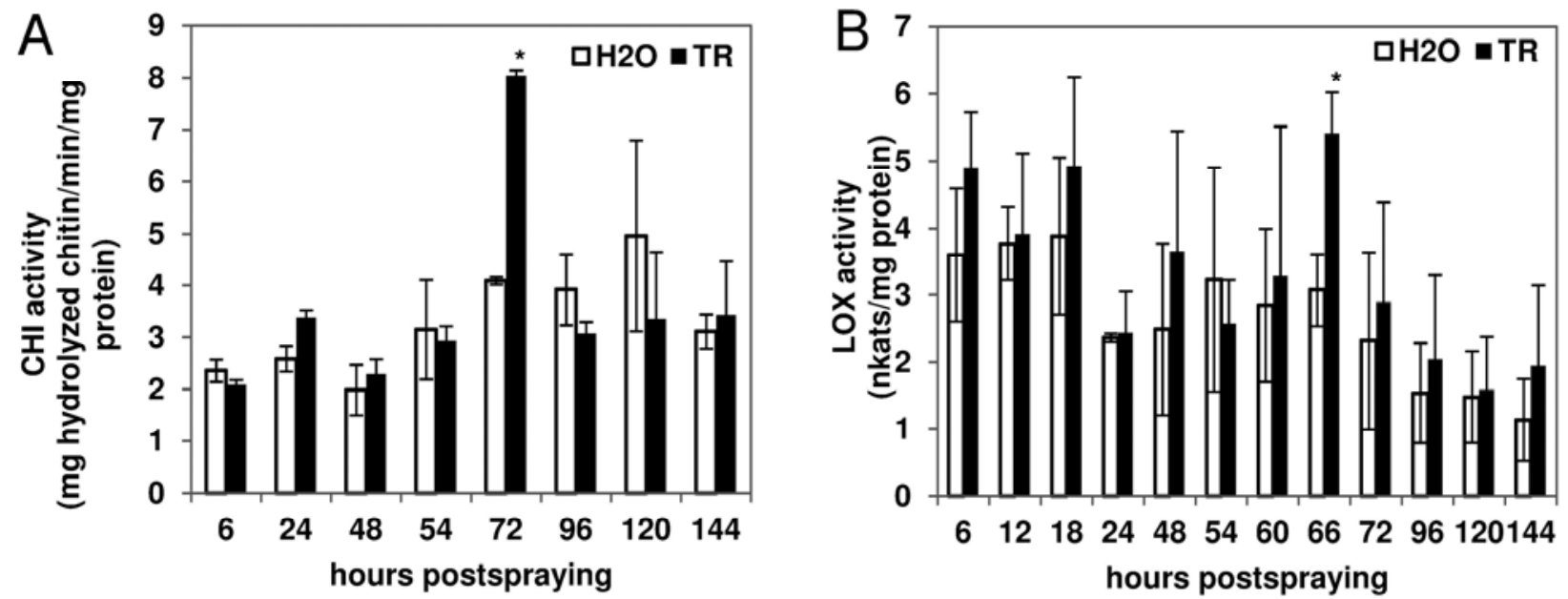

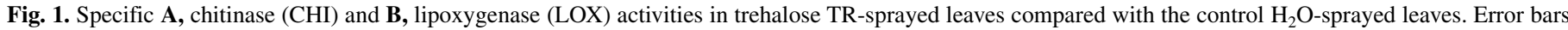

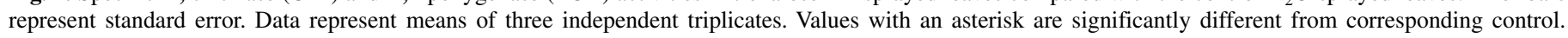
$\mathrm{CHI}=$ chitinase and LOX = lipoxygenase. 
fectious leaves are presented. However, only relevant benefits observed in TR-sprayed infectious leaves relative to reference $\mathrm{H}_{2} \mathrm{O}$-sprayed infectious leaves have been emphasized in the following section.

Chitinase and PR1-encoding gene expression are both early and lately induced in leaves sprayed with TR and subsequently inoculated with $B$. graminis f. sp. tritici. In comparison with the reference $\mathrm{H}_{2} \mathrm{O}$-sprayed infectious plantlets, TR spraying resulted in significant 2.1- and 3.45-fold increases of the chi gene expression at 21 and 96 hai, respectively (Fig. 3A) whereas no biological significant changes in the chil gene expression were recorded in TR-sprayed infectious plantlets over the time-course experiment (data not shown). Concerning the chi4 precursor gene expression, several increases were recorded in TR-sprayed infectious leaves compared with the levels measured in reference $\mathrm{H}_{2} \mathrm{O}$-sprayed infectious leaves. This resulted in increases by 2.5 , 3.6, and 3.5 during the first 9 hai as well as a 2.1-fold increase at 18 hai (Fig. 3B). At the enzymatic level, compared with the $\mathrm{H}_{2} \mathrm{O}$ sprayed infectious plantlets, a single significant $75 \%$ increase of the total chitinase activity was measured in TR-sprayed infectious leaves at 24 hai (Fig. 3C).

In TR-sprayed infectious plantlets, the level of PRI gene expression was significantly higher (2.5- and 2.2-fold increases) than in reference $\mathrm{H}_{2} \mathrm{O}$-sprayed infectious plantlets at 18 and 72 hai, respectively (Fig. 3D)

Induction of lox-encoding gene expression and LOX activity in wheat TR-treated infectious leaves occurred during the later hours of the infectious process. In TR-sprayed infectious wheat leaves, the level of lox gene expression was significantly higher than in the reference $\mathrm{H}_{2} \mathrm{O}$-sprayed infectious plantlets at 18,72 , and 96 hai, with ratios of $2.3,10.3$, and 4.2, respectively (Fig. 3E). Moreover, in TR-sprayed infectious wheat leaves, LOX activity was significantly induced, with 85 and 204\% increases compared with reference $\mathrm{H}_{2} \mathrm{O}$-sprayed infectious leaves at 72 and 96 hai, respectively (Fig. 3F).

Low and several upregulations of PI-PLC2 and ltp gene expression were respectively induced in TR-sprayed wheat plantlets upon infection with $B$. graminis f. sp. tritici. The PI$P L C 2$ gene expression increase did not exceed a 1.5 factor in TRsprayed infectious leaves compared with $\mathrm{H}_{2} \mathrm{O}$-sprayed infectious leaves 18 to 24 hai (Fig. 4A).

In TR-sprayed infectious leaves, significant 2.2-, 3.5-, and 2.1fold increases of the ltp gene's expression were observed at 18 , 24, and 96 hai, respectively, compared with $\mathrm{H}_{2} \mathrm{O}$-sprayed infectious leaves (Fig. 4B).
OXO- and GSTF-encoding gene expression profiles remained unchanged in TR-treated infectious leaves. TR treatment failed to induce any significant change in the oxo and gst $F$ gene expression profile when compared with reference $\mathrm{H}_{2} \mathrm{O}$ sprayed infectious leaves (Fig. 4C and D). At the enzyme level, no statistically significant changes in the OXO and GST activities were recorded in TR-sprayed infectious leaves compared with $\mathrm{H}_{2} \mathrm{O}$-sprayed infectious leaves (data not shown).

Relation between gene expression levels and infectious structures frequencies of $\boldsymbol{B}$. graminis $\mathbf{f}$. sp. tritici. The plane of the two first axes of the CA described $76.17 \%$ of the total inertia (Fig. 5), with $42.7 \%$ for axis I and $33.5 \%$ for axis II. Relative contributions of observations along the first two axes of the CA were expressed as percentages, which allowed us to assess their importance to axis structuring and are indicated within brackets. The right positive side of axis I was essentially structured by $\mathrm{H}_{2} \mathrm{O}$-sprayed infectious wheat plantlets at 3 hai $\left(\mathrm{H}_{2} \mathrm{O} 3\right.$ hai; $15.3 \%$ relative contribution) and TR-sprayed infectious wheat plantlets at 24 hai (TR 24 hai; 12.5\%), along with lox gene expression $(34.6 \%)$. It was strongly associated with the high frequency of ungerminated conidia and conidia with AGT without a penetration peg (infectious stages $\mathrm{A}$ and $\mathrm{D}$, respectively). Water-sprayed infectious wheat leaves at 48 hai $\left(\mathrm{H}_{2} \mathrm{O} 48\right.$ hai) and $P R 1$ gene expression contributing at 26.6 and $34.4 \%$, respectively, to axis I were represented on the left negative side. This gene's expression in the control leaves could be related to the high frequency of conidia with haustorial body either fully formed or in an early developmental stage (infectious stages $\mathrm{F}$ and $\mathrm{G}$, respectively).

Axis II revealed two main groups of observations. The negative part of axis II was mainly characterized by observations made at 12 and 21 hai for both conditions $\left(\mathrm{H}_{2} \mathrm{O}\right.$ and TR at 12 and 21 hai; $12 \%$ ) as well as by oxo and chil gene expression (reaching relative contributions $>25 \%$ ). Induction of these gene expressions was clearly associated with the high frequency of conidia with PGT and AGT occurring in both water- and TR-treated leaves (infectious stage $\mathrm{C}$ ). On its positive part, a group consisting of $\mathrm{H}_{2} \mathrm{O}$ sprayed infectious leaves at 3 hai $\left(\mathrm{H}_{2} \mathrm{O} 3\right.$ hai; $\left.13.4 \%\right)$ and $\mathrm{H}_{2} \mathrm{O}$ - and TR-sprayed infectious leaves at 96 hai $\left(\mathrm{H}_{2} \mathrm{O} 96\right.$ hai and TR 96 hai; 2.0 and $10.4 \%$, respectively) corresponded to high lox gene expression. This group was also associated with the high frequency of fungal colonies (infectious stage $\mathrm{H}$ ). Thus, the impact of TR treatment is clearly highlighted: TR induces a high lox gene expression (Fig. 3E) at the end of the experiment associated with reduced fungal colonies (infectious stage $\mathrm{H}$ ) with 40 versus $70 \%$ in water-sprayed leaves (data not shown).
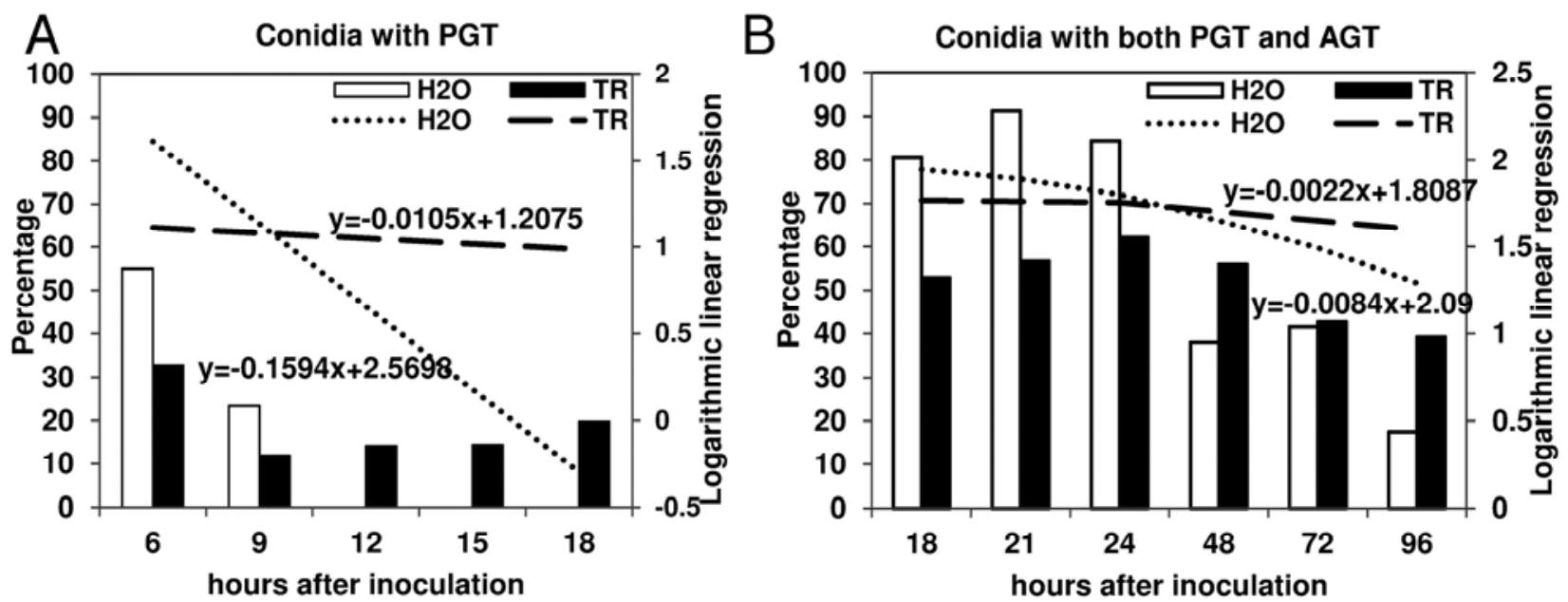

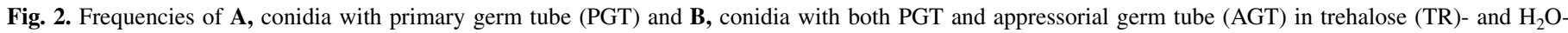

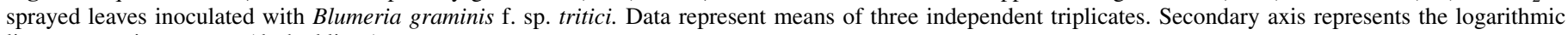
linear regression outputs (dashed lines). 
Defense-related gene expression profile in wheat leaves after TR infiltration. Early and high inductions of PR-encoding gene expression as well as CHI activity were observed upon TR infiltration. In TR-infiltrated wheat leaves, the chi gene expression was significantly induced between 6 and $18 \mathrm{hpi}$, with two peaks of 27.6- and 22.6-fold increase at 9 and $15 \mathrm{hpi}$, respectively, compared with the control water-infiltrated leaves (Fig. 6A). After the same treatment, the chil gene expression was significantly
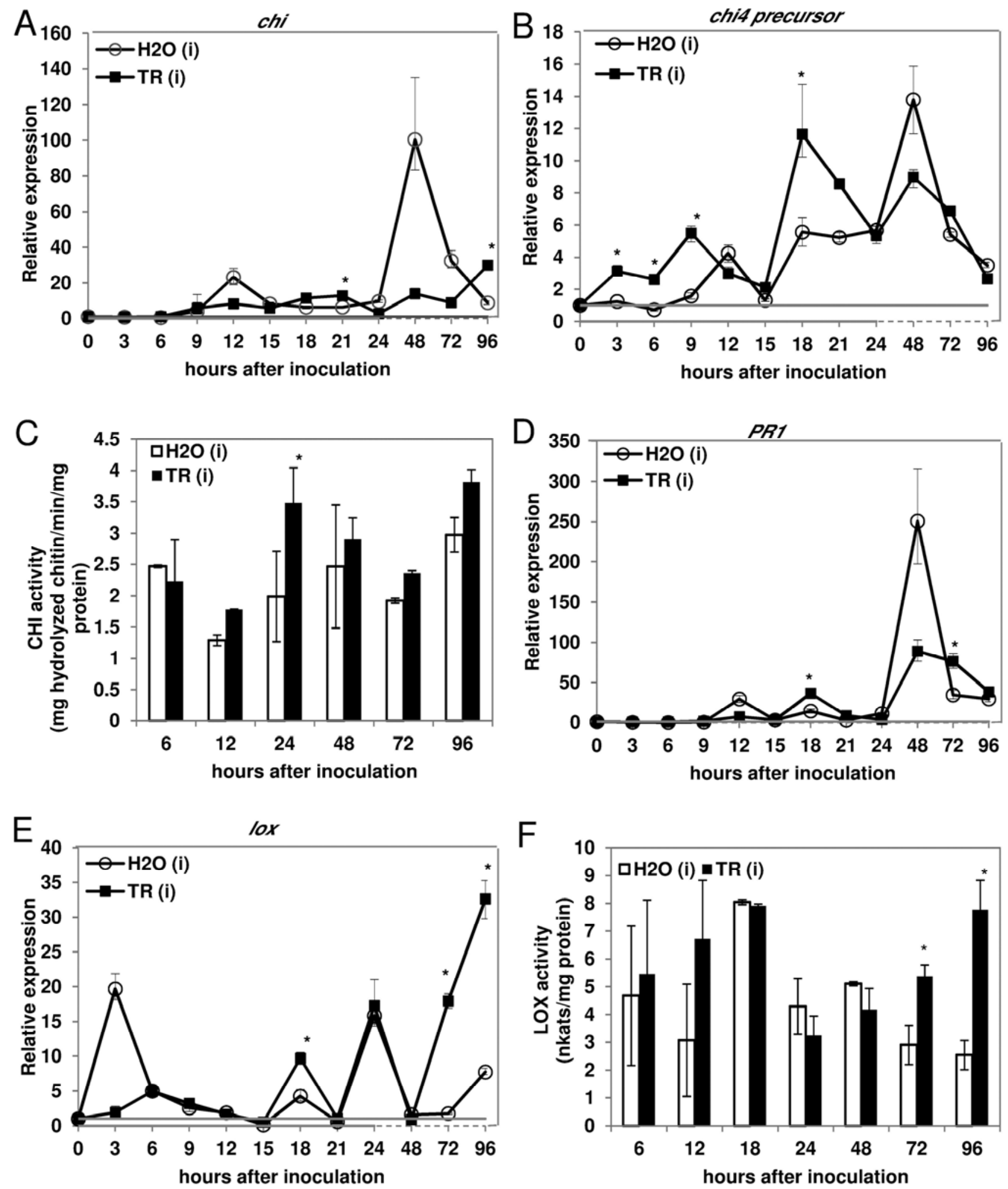

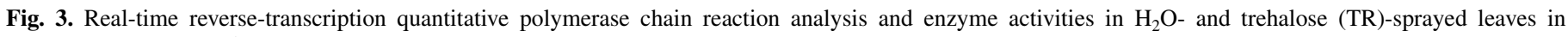

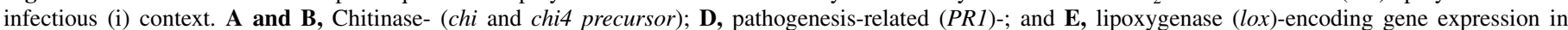

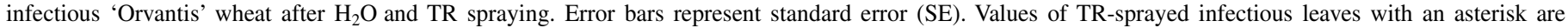

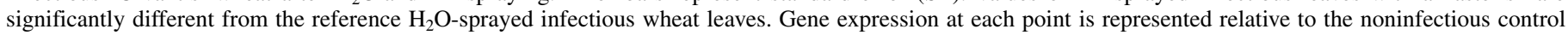

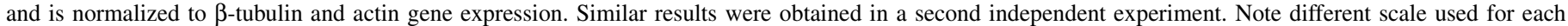

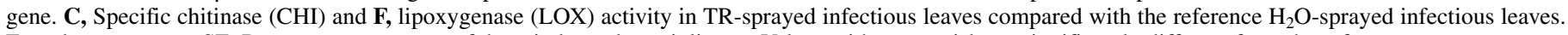
Error bars represent SE. Data represent means of three independent triplicates. Values with an asterisk are significantly different from the reference. 
induced as soon as 3 hpi to reach a maximum of 23.7-foldincrease at 9 hpi and then rapidly decreased with 14.4- and 8.8fold increases at 12 and 15 hpi. From 18 until 48 hpi, this gene's expression remained rather stable, with an average 2.3 -fold increase (Fig. 6B). The chi4 precursor gene transcripts accumulated significantly during the whole time-course experiment, except on 21 and $96 \mathrm{hpi}$, with a maximum 17-fold increase recorded at $9 \mathrm{hpi}$ $(P=0.054)$. It was still induced to 4.2 - and 3.6-fold increases at 12 and 15 hpi, respectively, before reaching levels of $<2$-fold increase at the remaining sampling points (Fig. 6C). In TR-infiltrated wheat leaves, total chitinase activity significantly increased by 73.8 and $88.7 \%$ compared with the control waterinfiltrated leaves at 6 and $18 \mathrm{hpi}$, respectively. No significant changes occurred 24 to 96 hpi (Fig. 6D).

TR infiltration significantly induced a 62.1 -fold increase of the PRl gene expression at $6 \mathrm{hpi}$, rising to 86.8- and 90.7fold increases at 9 to $12 \mathrm{hpi}$. A lower 21.9-fold increase, compared with water-infiltrated leaves, was recorded at $15 \mathrm{hpi}$ as well as an additional late upregulation with a 12.3-fold increase at 21 hpi (Fig. 6E). An early upregulation of the oxo gene was also observed in TR-infiltrated leaves during the first hour post infiltration, with a maximum threefold increase at $12 \mathrm{hpi}$ (Fig. 7A). However, no significant changes in the OXO activity were recorded in wheat leaves upon TR-infiltration (data not shown).
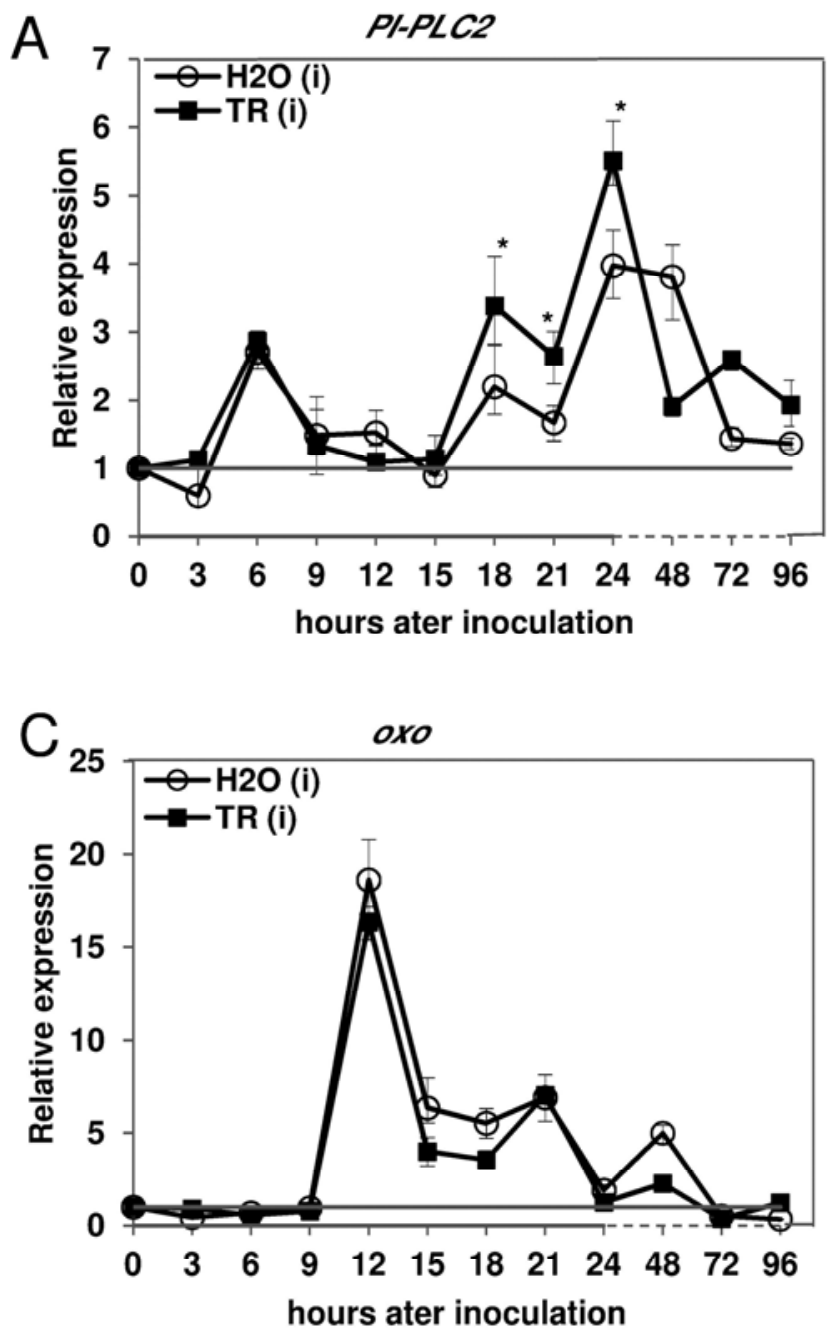

TR infiltration induced little if any upregulation of lox, gstF, $P I-P L C 2$, and ltp genes as well as corresponding activities. The expression of the lox, gst F, PI-PLC2, and ltp genes was significantly induced upon infiltration with TR; however, these inductions are not biologically relevant because they do not exceed the twofold threshold (Fig. 7B to E). Furthermore, TR infiltration did not induce any significant changes in the LOX and GST activities at all sampling points (data not shown).

\section{DISCUSSION}

In the past 10 years, fundamental research has been oriented toward sugar-mediated plant immunity in order to explore the feasibility of using sugar-like compounds as alternatives to conventional agrochemicals (39). Several recent studies focused on the ability of sugars treatments to induce crop resistance to pathogens. Exogenous sucrose application induced resistance on apple trees against Cydia pomonella and in rice plants to Magnaporthe oryzae (30 $\mu \mathrm{M}$ and $300 \mathrm{mM}$, respectively) (16,20). Foliar treatments of tomato with sucrose $(100 \mathrm{ppm} ; 300 \mu \mathrm{M})$ and melon with fructose $(10 \mathrm{ppm} ; 60 \mu \mathrm{M})$ drastically reduced the symptom severity due to Botrytis cinerea (12). It has also been documented that allose found in Protea rubropilosa (African shrub) and psicose found in cane molasses, wheat, and Itea virginica plants are rare sugars that induce rice resistance to bacterial blight when
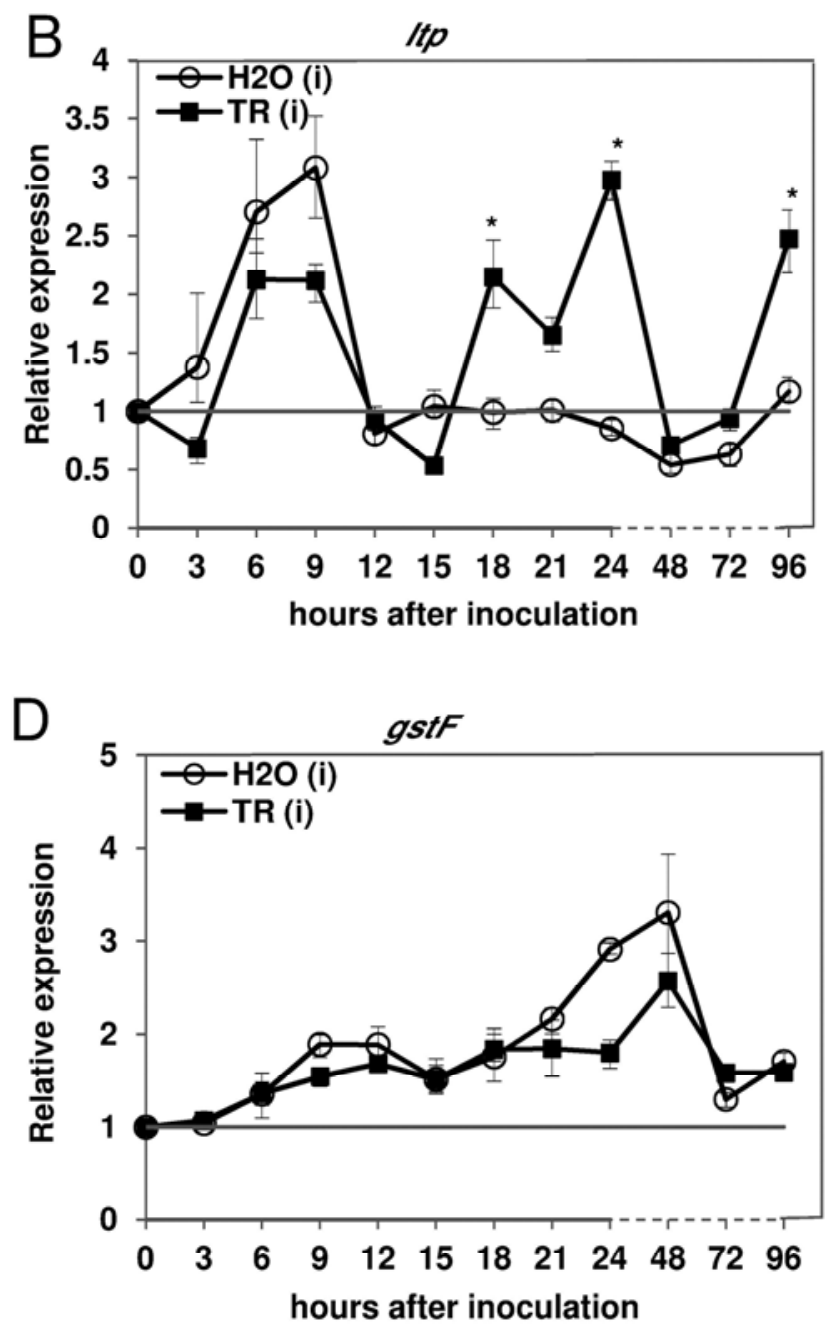

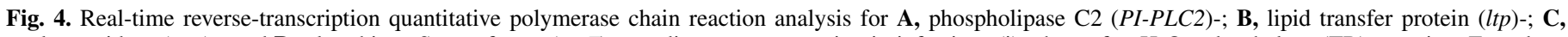

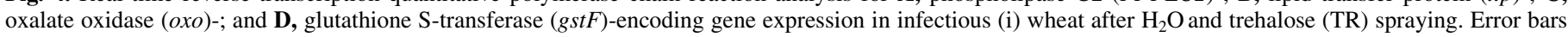

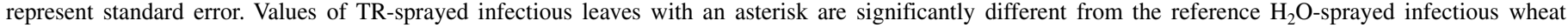

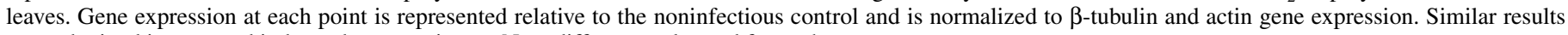
were obtained in a second independent experiment. Note different scale used for each gene. 
used at 25 and $5 \mathrm{mM}$, respectively, by feeding through the root system $(24,25)$. In comparison, the $15 \mathrm{~g} / \mathrm{liter} \mathrm{TR}$ solution we applied on the wheat-powdery mildew interaction corresponds to a $44 \mathrm{mM}$ concentration.

One of the main objectives of our work was to assess, in infectious context, the TR effect on nine selected defense-related gene expressions, in order to detect metabolisms and defense pathways triggered by TR while protecting wheat against Blumeria graminis f. sp. tritici. In a first step, our time-course experiment allowed us to assess TR elicitor effect on wheat defense activation in noninfectious conditions. Then, we investigated the priming effect of TR through the differences that occurred on gene expression profiles between TR- and $\mathrm{H}_{2} \mathrm{O}$-sprayed infectious plantlets, both profiles being established relative to the noninfectious $\mathrm{H}_{2} \mathrm{O}$-sprayed plantlets. The relationship between gene expression, enzyme activities, and microscopic approach strengthened our understanding of the wheat behavior after TR spraying.

Repression of B. graminis f. sp. tritici infection by TR spraying is associated with the induction of wheat PR-encoding genes. In noninfectious context, several waves of elicitation of chi, chil (which encodes a vacuolar chitinase), chi4 precursor (which encodes an apoplastic chitinase), and PR1 gene expression were observed upon TR spraying, as well as a significant increase in the total chitinase activity. Therefore, TR induces this PR- encoding gene expression and CHI activity in wheat, even in the absence of the pathogen. In infectious context, TR induced a higher chi4 precursor gene expression the first hour after inoculation, whereas induction of $c h i$ and $P R l$ gene expression was observed at the final stages of the infectious process. Our results show that the early upregulation of the chi4 precursor gene expression and the induction of chitinase activity appear to be a specific marker of partial resistance induced by TR. The latter could enhance the activity of such apoplastic-encoded chitinase, generally involved in the early stages of pathogenesis because apoplastic chitinases release elicitor molecules (PAMPs) from the hyphae that penetrate the intracellular space. Such molecules may transfer the information about infection and bind to receptors that switch on the synthesis of vacuolar chitinases such as the chitinase encoded by the chil gene. Vacuolar chitinases would then degrade the newly synthesized chains of chitin, eventually repressing fungal growth $(23,26)$. Furthermore, Reignault et al. (49) noticed that the size of $B$. graminis f. sp. tritici colonies remained constant while their number decreased after TR spraying. Therefore, TR interferes with fungal infection attempts but does not restrict fungal growth once the penetration has occurred. Indeed, the observations conducted here in planta showed that conidia with PGT and conidia with both PGT and AGT occurred for a longer time than in $\mathrm{H}_{2} \mathrm{O}$-treated controls leaves (Fig. 2A and B) and were the most abundant category until 72 hai (data not

Axes $\mathrm{F} 1$ and $\mathrm{F} 2: \mathbf{7 6 , 1 7} \%$

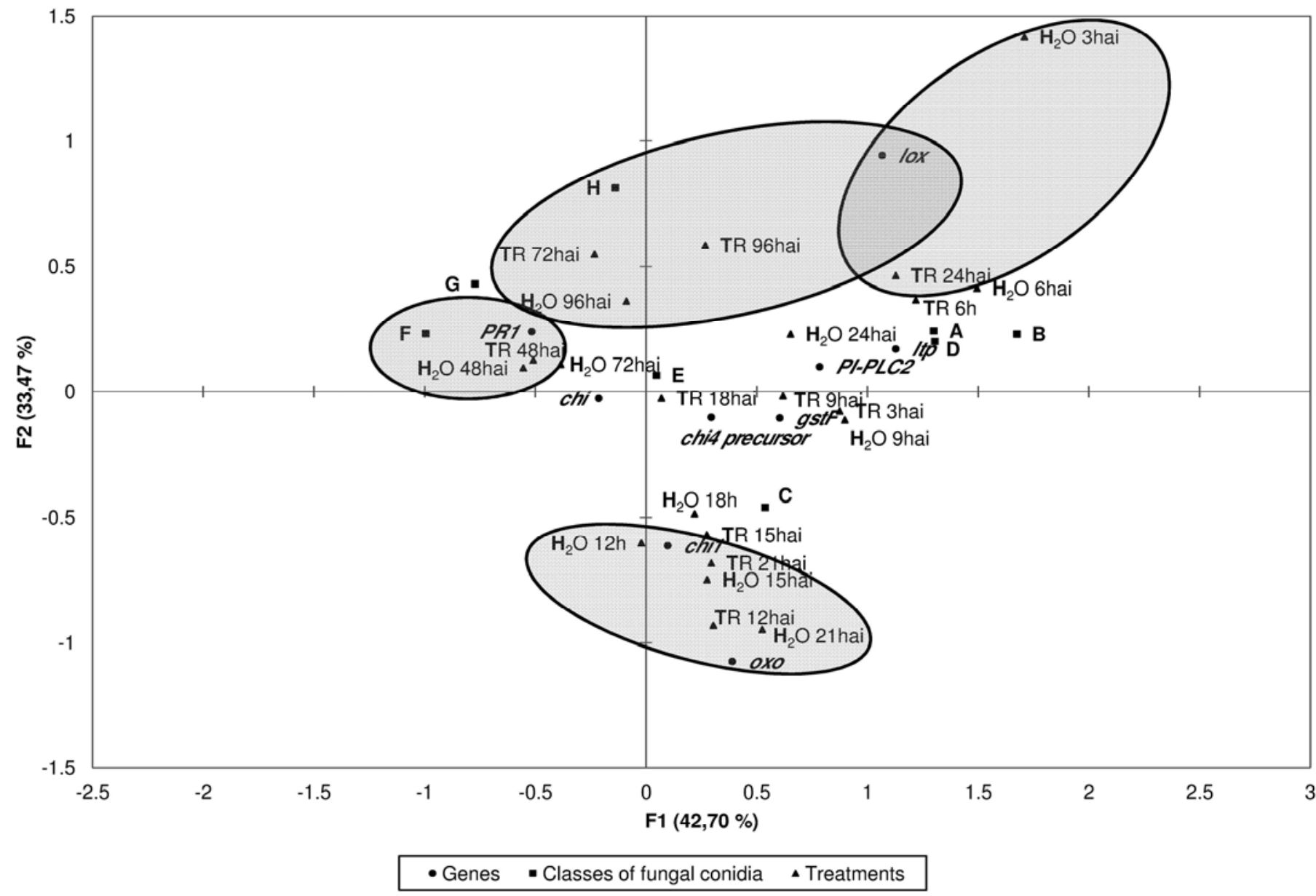

Fig. 5. Results from the correspondence analysis applied to the gene expression X conditions of the time-course experiment. Total variance for axis I-II plan is 76.17\%. Projections of treatments and gene expression during the time course experiment are presented by triangles and circles, respectively. TR $=$ trehalosesprayed leaves, $\mathrm{H}_{2} \mathrm{O}=$ control condition, and time code = sampling time over the 96-h experiment. Microscopic events illustrating the life cycle were added as supplementary observations (squares). A = ungerminated conidia, B = conidia with primary germ tube (PGT), C = conidia with PGT and appressorial germ tube (AGT), D = conidia with a long AGT without a penetration peg, $\mathrm{E}=$ conidia with a long AGT with a penetration peg, $\mathrm{F}=$ conidial AGT leading to haustorial body, $\mathrm{G}=$ conidial AGT with fully-formed haustorium, and $\mathrm{H}=$ fungal colony. 
shown). This suggests that previously recorded protection levels result from events blocked at earlier developmental stages. Interestingly, among the tested chitinase-encoding genes, only chi4 precursor gene expression, encoding an apoplastic chitinase, is associated with the restriction of $B$. graminis f. $\mathrm{sp}$. tritici infectious process at early steps before penetration attempts. It may render useless the induction of a wheat vacuolar chitinase encoded by the chil gene to repress such an ectoparasitic pathogen.
Similarly to the late upregulation of the chi gene described in our pathosystem, this chi gene expression proved to be highly induced in a wheat cultivar susceptible to $M$. graminicola (Z. tritici) at the final stages of the pathogen's cycle (54). Moreover, these authors recorded a high chitinase activity in whole-leaf extracts in resistant infectious cultivars, as reported in the case of our compatible interaction after TR spraying.

Although Aghdasi et al. (1) did not record any upregulation of a PR1-encoding gene expression in A. thaliana $24 \mathrm{~h}$ after treatment

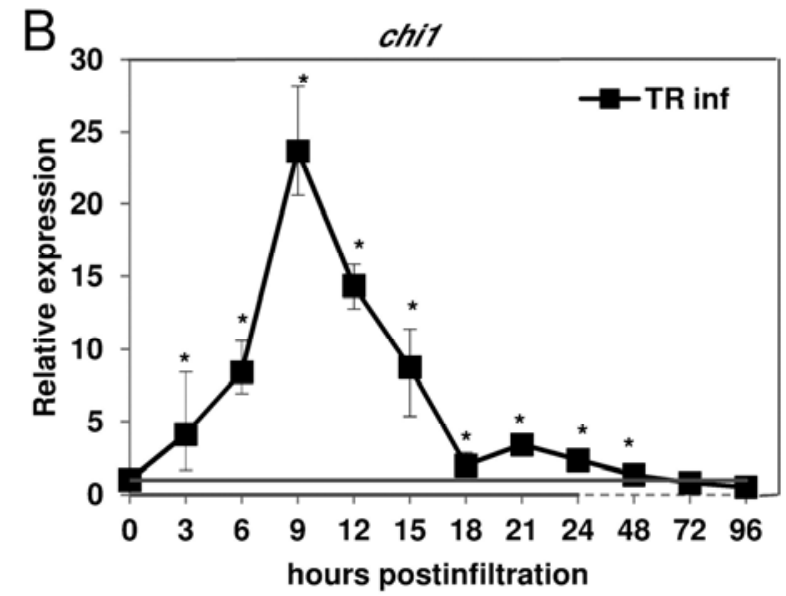

D

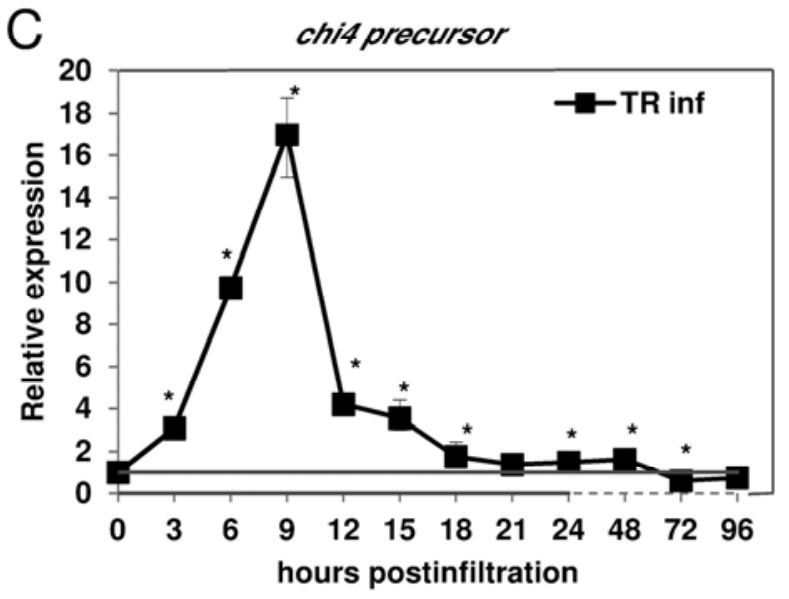

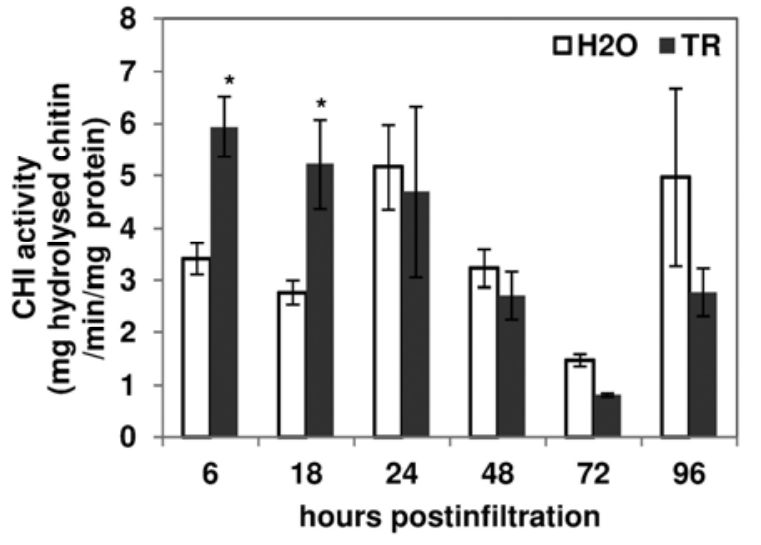

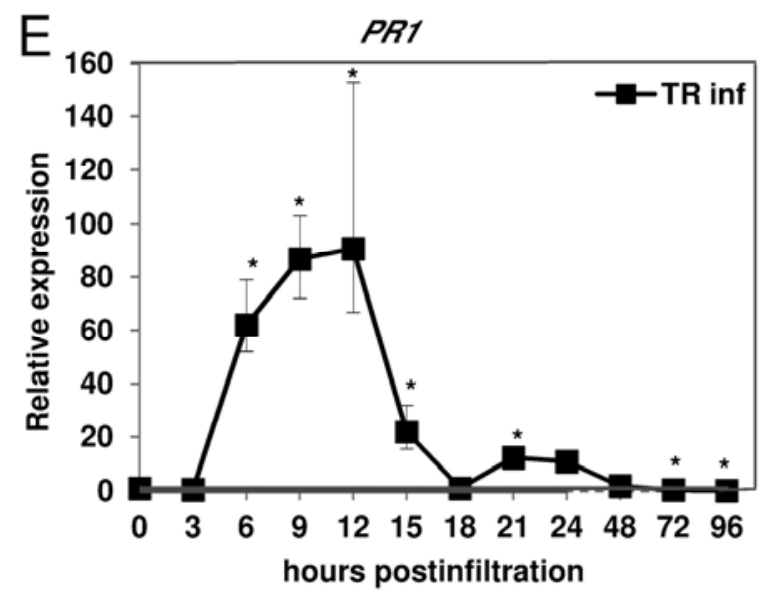

Fig. 6. Real-time reverse-transcription quantitative polymerase chain reaction analysis and enzyme activities in wheat post trehalose (TR) infiltration. A to C, Chitinases (chi, chil, and chi4 precursor); and E, pathogenesis-related (PRI)-encoding gene expression. Error bars represent standard error (SE). Values with an asterisk are significantly different from corresponding water-infiltrated control. Gene expression at each point is relative to the water-infiltrated noninfectious control and is normalized to $\beta$-tubulin and actin gene expression. Similar results were obtained in a second independent experiment. Note different scale used for each gene. D, Specific chitinase (CHI) activity in TR-infiltrated leaves compared with the control $\mathrm{H}_{2} \mathrm{O}$-infiltrated leaves. Error bars represent SE. Data represent means of three independent triplicates. 
with a $100 \mathrm{mM}$ TR solution, we describe here, for the first time, the TR ability to induce the PR1-encoding gene expression in wheat. Unlike TR, well-known resistance inducers such as SA, dichloroisonicotinic acid, or benzothiadizole failed in inducing wheat PR1-encoding gene expression (40). The role of this PR1 protein is yet to be elucidated in wheat. However, possible antifungal activities were assigned to a PR1 protein in tomato, broad bean, and tobacco against Phytophthora infestans, Botrytis cinerea, and Uromyces fabae $(28,42,48)$.

Lipid signaling, mainly though the LOX pathway, is associated with reduced $B$. graminis f. sp. tritici colonies in TRsprayed wheat. Similarly to the results obtained with the chitin- ase-encoding genes, and despite a single increase of the LOX activity, several upregulations of lox gene expression were observed in TR-sprayed wheat leaves during the whole time-course experiment in noninfectious context. In infectious context, TR spraying also induced high upregulations of the lox gene expression and sustainable increase of the LOX activity at the final steps of the infectious process.

LOX enzymes catalyze the dioxygenation of polyunsaturated fatty acids and lead, when it is followed by the allene oxide synthase (AOS), to the downstream production of jasmonic acid. Otherwise, it leads to the synthesis of oxylipins, which are potent signaling molecules involved in the defense reactions in both
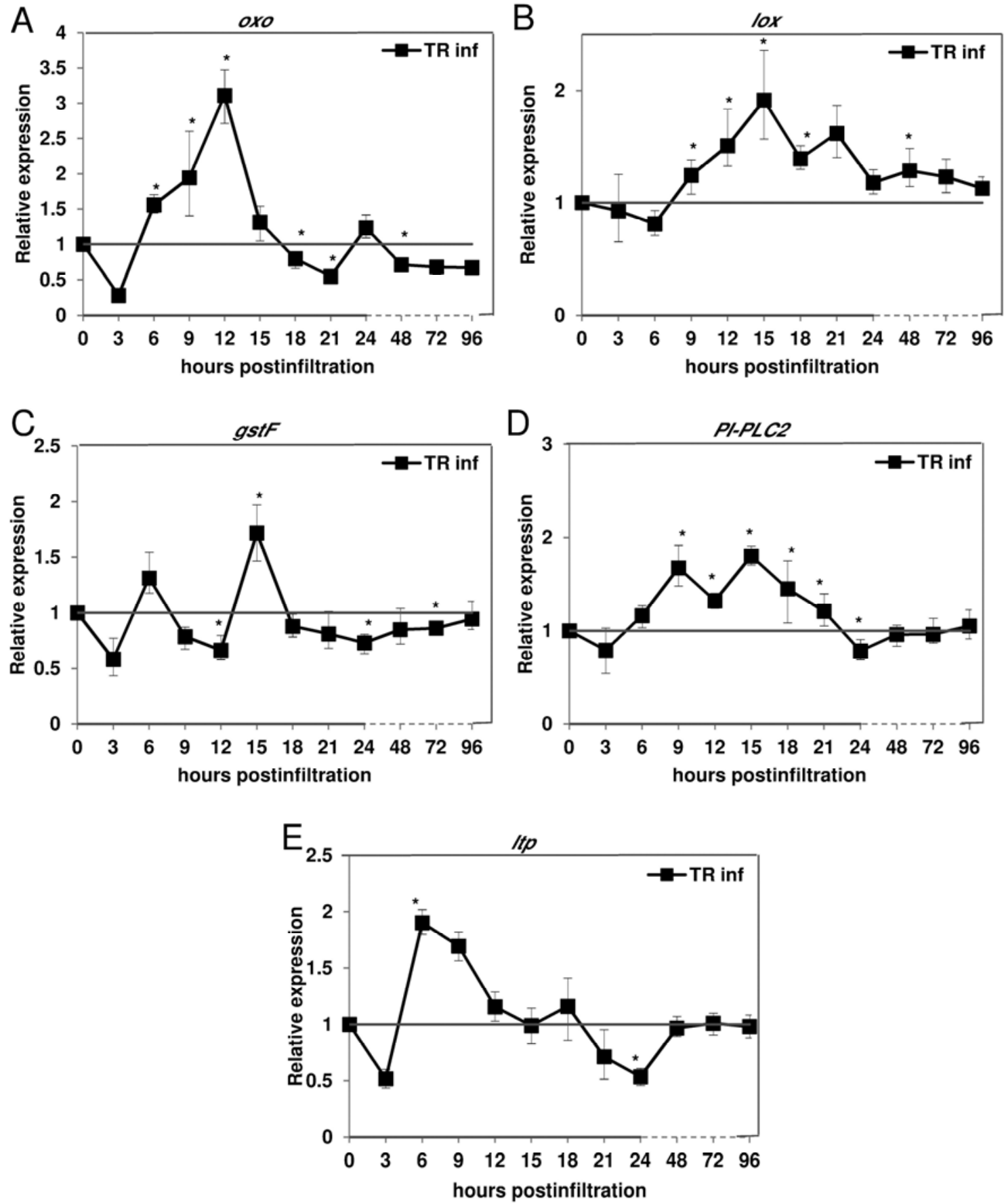

Fig. 7. Real-time reverse-transcription quantitative polymerase chain reaction analysis for A, oxalate oxidase (oxo)-; B, lipoxygenase (lox)-; C, glutathione Stransferase ( $g s t F)$-; D, phospholipase C2 (PI-PLC2)-; and E, lipid transfer protein (ltp)-encoding gene expression in wheat post trehalose (TR) infiltration. Error bars represent standard error. Values with an asterisk are significantly different from corresponding water control. Gene expression at each point is represented relative to the water-infiltrated noninfectious control and is normalized to $\beta$-tubulin and elongation factor $1 \alpha$ gene expression. Similar results were obtained in a second independent experiment. Note different scale used for each gene. 
animals and plants (31). Some conflicting results on the octadecanoid pathway have been previously reported through several examples. Transcripts of a lox-2-encoding gene significantly decreased in A. thaliana seedlings after treatment with exogenous TR (3) while TR induced an upregulation of the AOS-encoding gene in A. thaliana seedlings (1). Furthermore, other sugars such as sucrose stimulated the expression of a lox-A-encoding gene in treated soybean leaves (53). Our results clearly showed an elicitor effect of TR on the lox gene expression, as well as on LOX activity induction, extending the observations of Renard-Merlier et al. (50) at the enzymatic level. Meanwhile, in planta TR was able to reduce the frequency of occurring fungal colonies at the latest stages of Blumeria graminis $\mathrm{f}$. sp. tritici infectious process simultaneously with the activation of the lox gene expression and the LOX activity, according to the CA (Fig. 5, positive side of axis II). Similarly, this lox gene has been reported to be involved in the resistance induction by benzothiadizole during the wheatpowdery mildew interaction (21), even though no indication regarding the nature of this gene-encoding for either LOX9 or LOX13 - has been reported yet. Therefore, the protection level achieved by TR is strongly associated with the lipid signaling defense reaction. In addition to the concordance with the enzymatic results obtained by Renard-Merlier et al. (50) concerning the absence of LOX stimulation between 24 and 48 hai, further sampling conducted here allowed us to highlight later sustainable stimulation of the LOX activity by TR in infectious context.

The early elicitor effect of TR on the ltp gene expression observed in wheat took place earlier than the one reported in A. thaliana, only $24 \mathrm{~h}$ after treatment with TR (1). Interestingly, the potentiation of this gene occurred simultaneously with the one of lox at the final steps of the infectious process, suggesting that their binding properties may involve their binding properties to lipids generated through the octadecanoid pathway. LTPs could participate in the protection level obtained through TR spraying because they are generally involved in intracellular phospholipid traffic and may present antifungal activity $(29,58)$.

Phospholipase $\mathrm{C}$ is thought to be involved in the transient accumulation of phosphatidic acid (PA), a multifunctional stress signaling lipid in plants (59). Under infectious conditions, a very low potentiation of the PI-PLC2 gene expression was achieved upon TR treatment, whereas no elicitation of this gene expression was recorded post TR spraying in wheat. One could think that PA production is not accomplished, at least through the PLC2 pathway.

The tested ROS-generating and scavenging genes and enzymes are not markers of TR induced resistance in wheat. Elicitation and potentiation effects on ROS metabolism were surprisingly reduced in the case of TR, given the common association between them (1). In wheat and other cereals, OXO has been considered as a marker of pathogen infection in powderymildew cereal interaction (32). Indeed, $\mathrm{OXO}$ generates $\mathrm{H}_{2} \mathrm{O}_{2}$, a ROS classically involved in papillae formation (9). A unique upregulation of the oxo gene expression was recorded post TR spraying without any significant change in the corresponding OXO activity. Moreover, this enzyme was not responsive to TR spraying during the whole time-course experiment in infectious context, meeting the results reported by Renard-Merlier et al. (50). However, these authors specifically reported increased $\mathrm{H}_{2} \mathrm{O}_{2}$ accumulation at the penetration site only after TR treatment. According to our results, the $\mathrm{H}_{2} \mathrm{O}_{2}$ production does not involve $\mathrm{OXO}$, and may occur through another $\mathrm{H}_{2} \mathrm{O}_{2}$-generating enzyme such as superoxide dismutase.

Nevertheless, TR failed to induce either any significant upregulation of the investigated GST phi-encoding gene expression or the stimulation of GST activity during the whole time-course experiment in both noninfectious and infectious contexts. Conversely, many studies showed inductions of GST-encoding genes in A. thaliana under TR treatment (1), as well as the accumulation of class phi GST (AtGSTF2) polypeptide (4). Because GST is produced upon ROS-mediated oxidation of lipids (34), these findings suggest the occurrence of an oxidative stress upon TR treatment in A. thaliana. However, in wheat, none of these observations has been reported.

TR elicits wheat defense genes and potentiates responses during a powdery mildew infection. The time-course experiment in both noninfectious and infectious contexts allowed us to deepen the conclusions we drew about the eliciting or priming effect of TR on wheat defense mechanisms. In fact, no previous studies investigating the effect of resistance inducers on gene expression conducted either high-frequency sampling or longtime-course experiments. These two procedures are necessary to highlight the possible elicitor effect of such resistance inducers from the moment of application until the advanced noninoculated sampling points, in parallel with the latest stages of the infectious process. Because elicitation of tested genes occurred after TR spraying in the absence of $B$. graminis f. sp. tritici, all recorded inductions of these genes' expression could not be considered the result of a genuine priming effect. In the presence of a pathogen, a prime state is defined as a physiological condition in which plants are able to better or more rapidly mount defense responses, or both, to biotic stresses $(5,10)$. In addition, priming is typically induced by molecules without any elicitor property such as $\alpha$ aminobutyric acid (63) or used at concentrations that do not stimulate defense responses, as in the case of SA or benzothiadiazole in noninfectious context $(30,61)$. In order to reduce the elicitation of wheat defense-related genes in noninfectious conditions, priming could be reached by reducing the concentration of TR solution, thus limiting its effects in noninfectious conditions. However, an insight regarding gene expression levels in both TRsprayed noninfectious and infectious leaves allowed us to clearly establish that gene expression level is more important in the presence of $B$. graminis f. sp. tritici compared with noninfectious conditions. Thus, such an over-induction of wheat defense responses against $B$. graminis f. sp. tritici, despite its slight occurrence in a noninfectious context, will be considered to be a potentiation of plant defense mechanisms by TR.

Are defenses activated upon TR treatment due to osmotic stress or true elicitation? The direct infiltration of wheat leaves with TR solution was undertaken for two purposes: (i) to overcome any loss due to difficult penetration or nonhomogeneous sprayings and (ii) to evaluate any osmotic stress due to high doses of TR infiltration. Interestingly, only PR1 and chitinase transcripts accumulated in these conditions, together with a rapid chitinase activity that lasted for $18 \mathrm{hpi}$. These PR proteins are not involved so far in osmotic stress or ROS metabolism. Moreover, no induction of either OXO or class phi GST enzymes, the latter being a well-known marker of osmotic stress upon TR treatment in Arabidopsis, was recorded at the gene and protein levels. Furthermore, the infiltrated mesophyll cells remained perfectly green and tonic. Because the infiltrated leaves kept a fully linear vertical port, which is widely known to be related to a state of turgidity, one could think that no plasmolysis occurred after high input of TR through infiltration. Given the fact that these results were obtained by TR infiltration, with levels far higher than physiological levels occurring in plants such as wheat (13), our findings confirm the hypothesis that TR must be considered a true resistance inducer of wheat defense responses, thus answering the question pointed out by Fernandez et al. (15) as to whether wheat defenses under TR spraying were triggered following osmotic stress or by true elicitation. On the other hand, under biotic stress, protective or adverse effects of TR have been described in several plants. It has been demonstrated, for instance, that TR is a key metabolite in plant-rhizobacteria interactions (56). However, TR can also act as a key virulence factor in pathogens, such as Plasmodiophora brassicae on A. thaliana. By releasing TR in plants, pathogens might be able to exploit the plant's TR-sensing 
system and alter plant carbohydrate metabolism (6). Moreover, TR is the starting point for chitin synthesis (38). The enhanced defense mechanisms described here could be due to the perception of TR as a virulence factor or a chitin precursor in wheat leaves.

Furthermore, TR is a highly hydrophilic molecule and its limited penetration through the plant cuticle could interfere with its efficiency in triggering wheat defense reactions. Thus, infiltration could help directly bring together TR with a possible corresponding receptor. Indeed, sugars and their analogs could be sensed at the plasma membrane by sugar transporters or transporter-like proteins or by specific sugar receptors (52), suggesting a PAMP-like behavior. TR acting as a PAMP is a hypothesis that has yet to be formally confirmed, even though previous experiments support it. Similar protection levels $(50 \%)$ and inductions of defense marker activities such as phenylalaline ammonia-lyase (PAL) or peroxydase (PO) were achieved in a cut detached-leaves assay with a TR solution of $0.01 \mathrm{~g} /$ liter compared with sprayings of $15 \mathrm{~g} /$ liter (49). These data suggest that direct TR application could compensate for the difficulty of such a hydrophilic molecule in penetrating the hydrophobic plant cuticle efficiently. Thus, TR is able to induce plant resistance and defense reactions at low concentrations because it is provided directly into the leaf mesophyll by infiltration. Concerning the physiological response of wheat to TR infiltration, PR1- and chitinase-encoding genes showed much higher induction levels in this condition compared with the ones observed post TR spraying. It seems that TR infiltration through the hydrophobic cuticle and stomata leads to higher TR perception and, thus, to higher plant responses. In general, efficiency of plant defense stimulation usually provides good reproducible results in the laboratory but is often disappointing in the field $(7,44)$. Thus, it is necessary to conduct further tests in order to determine the optimal TR concentration that ensures an efficient protection of wheat against B. graminis $\mathrm{f}$. sp. tritici by successful stimulation of defense mechanisms. Synthesis of TR derivatives by adding supplementary chemical functions that could facilitate its penetration should also be considered: the advantages earned by such a manipulation are encouraging, as shown by the pair SA/HSA tested on the wheatpowdery mildew interaction $(41,50)$. Taken together, the above findings are consistent with the suggestion that exogenous TR is an important inducer of defense gene expression in wheat.

\section{ACKNOWLEDGMENTS}

C. Tayeh was supported by the French Ministry of National Education and Research. We thank F. Baillieul and L. Jacquens (URVCC-EA 2069, Reims, France) for their help in optimization of chitinase assays as well as T. Mazurier for his technical help.

\section{LITERATURE CITED}

1. Aghdasi, M., Smeekens, S., and Schluepman, H. 2008. Microarray analysis of gene expression patterns in Arabidopsis seedlings under trehalose, sucrose and sorbitol treatment. Int. J. Plant Prod. 2:309-332.

2. Avdiushko, S. A., Ye, X. S., Hildebrand, D. F., and Kuc, J. 1993. Induction of lipoxygenase activity in immunized cucumber plants. Physiol. Mol. Plant Pathol. 42:83-95.

3. Bae, H., Herman, E., Bailey, B., Bae, H. J., and Sicher, R. 2005. Exogenous trehalose alters Arabidopsis transcripts involved in cell wall modification, abiotic stress, nitrogen metabolism, and plant defense. Physiol. Plant. 125:114-126.

4. Bae, H., Herman, E., and Sicher, R. 2005. Exogenous trehalose promotes non-structural carbohydrate accumulation and induces chemical detoxification and stress response proteins in Arabidopsis thaliana grown in liquid culture. Plant Sci. 168:1293-1301.

5. Beckers, G. J., and Conrath, U. 2007. Priming for stress resistance: From the lab to the field. Curr. Opin. Plant Biol. 10:425-431.

6. Brodmann, D., Schueller, A., Ludwig-Müller, J., Aeschbacher, R. A., Wiemken, A., Boller, T., and Wingler, A. 2002. Induction of trehalase in Arabidopsis plants infected with the trehalose-producing pathogen
Plasmodiophora brassicae. Mol. Plant-Microbe Interact. 15:693-700.

7. Campbell, P. A., and Latorre, B. A. 2004. Suppression of grapevine powdery mildew (Uncinula necator) by acibenzolar-S-methyl. Vitis 43:209-210.

8. Chen, Y. T., Chen, Y. F., Li, S. F., Gao, S. G., Yan, H. F., Yang, W. X., and Liu, D. Q. 2011. Differential expression of near-isogenic line TcLr19 resistant to wheat leaf rust. Acta Physiol. Sin. 41:445-448.

9. Christensen, A. B., Thordal-Christensen, H., Zimmermann, G., Gjetting, T., Lyngkjær, M. F., Dudler, R., and Schweizer, P. 2004. The germinlike protein GLP4 exhibits superoxide dismutase activity and is an important component of quantitative resistance in wheat and barley. Mol. PlantMicrobe Interact. 17:109-117.

10. Conrath, U., Beckers, G. J., Flors, V., García-Agustín, P., Jakab, G., Mauch, F., Newman, M. A., Pieterse, C. M., Poinssot, B., Pozo, M. J., Pugin, A., Schaffrath, U., Ton, J., Wendehenne, D., Zimmerli, L., and Mauch-Mani, B. 2006. Priming: Getting ready for battle. Mol. PlantMicrobe Interact. 19:1062-1071.

11. Cortina, C., and Culianez-Macia, F. A. 2005. Tomato abiotic stress enhanced tolerance by trehalose biosynthesis. Plant Sci. 169:75-82.

12. Derridj, S., Arnault, I., Nicholas A. E., Birch, N. E., Elad, Y., Lombarkia, N., Couzi, P. P., and Auger, J. 2011. Les sucres solubles, une opportunité pour l'agriculture durable? Phytoma 640:10-14

13. El-Bashiti, T., Hamamcı, H., Öktem, H., and Yücel, M. 2005. Biochemical analysis of trehalose and its metabolizing enzymes in wheat under abiotic stress conditions. Plant Sci. 169:47-54.

14. El Chartouni, L., Randoux, B., Duyme, E., Renard-Merlier, D., Tisserant, B., Bourdon, N., Pillon, V., Sanssené, J., Durand, R., Reignault, P., and Halama, P. 2011. Correlation of cytological and biochemical parameters with resistance and tolerance to Mycosphaerella graminicola in wheat. Plant Biol. 14:11-21

15. Fernandez, O., Béthencourt, L., Quero, A., Sangwan, R., and Clément, C. 2010. Trehalose and plant stress response: Friend or foe? Trends Plant Sci. 15:409-417.

16. Ferré, E., Galy, H., Moulin, F., Clément, G., and Derridj, S. 2008. Le saccharose inducteur de résistance du pommier contre Cydia pomonella $l$. In: AFPP, 8th Int. Conf. Pests Agric. Montpellier, France.

17. Galinski, E. A. 1993. Compatible solutes of halophilic eubacteria: Molecular principles, water-solute interaction, stress protection. Cell. Mol. Life Sci. 49:487-496.

18. Garg, A. K., Kim, J. K., Owens, T. G., Ranwala, A. P., Do Choi, Y., Kochian, L. V., and Wu, R. J. 2002. Trehalose accumulation in rice plants confers high tolerance levels to different abiotic stresses. Proc. Natl. Acad. Sci. USA 99:15898-15903.

19. Golem, S., and Culver, J. N. 2003. Tobacco mosaic virus induced alterations in the gene expression profile of Arabidopsis thaliana. Mol. Plant-Microbe Interact. 16:681-688.

20. Gomez-Ariza, J., Campo, S., Rufat, M., Estopa, M., Messequer, J., Sequndo, B. S., and Coca, M. 2007. Sucrose-mediated priming of plant defense responses and broad-spectrum disease resistance by overexpression of the maize pathogenesis-related PRms proteins in rice plant. Mol. Plant-Microbe Interact. 20:832-842.

21. Görlach, J., Volrath, S., Knauf-Beiter, G., Hengy, G., Beckhove, U., Kogel, K. H., Oostendorp, M., Staub, T., Ward, E., Kessmann, H., and Ryals, J. 1996. Benzothiadiazole, a novel class of inducers of systemic acquired resistance, activates gene expression and disease resistance in wheat. Plant Cell 8:629-643.

22. Hofmann, J., El-Ashry, A. N., Anwar, S., Erban, A., Kopka, J., and Grundler, F. 2010. Metabolic profiling reveals local and systematic responses of host plants to nematode parasitism. Plant J. 62:1058-1071.

23. Kaku, H., Nishizawa, Y., Ishii-Minami, N., Akimoto-Tomiyama, C., Dohmae, N., Takio, K., Minami, E., and Shibuya, N. 2006. Plant cells recognize chitin fragments for defense signaling through a plasma membrane receptor. Proc. Natl. Acad. Sci. USA 103:11086-11091.

24. Kano, A., Gomi, K., Yamasaki-Kokudo, Y., Satoh, M., Fukumoto, T., Ohtani, K., Tajima, S., Izumori, K., Tanaka, K., Ishida, Y., Tada, Y., Nishizawa, Y., and Akimitsu, K. 2010. A rare sugar, d-allose, confers resistance to rice bacterial blight with upregulation of defense-related genes in Oryza sativa. Phytopathology 100:85-90.

25. Kano, A., Hosotani, K., Gomi, K., Yamasaki-Kokudo, Y., Shirakawa, C., Fukumoto, T., Ohtani, K., Tajima, S., Izumori, K., Tanaka, K., Ishida, Y., Nishizawa, Y., Ichimura, K., Tada, Y., and Akimitsu, K. 2011. D-psicose induces upregulation of defense-related genes and resistance in rice against bacterial blight. J. Plant Physiol. 168:1852-1857.

26. Kasprzewska, A. 2003. Plant chitinases-regulation and function. Cell. Mol. Biol. Lett. 8:809-824.

27. Khalil, H. B., Wang, Z., Wright, J. A., Ralevski, A., Donayo, A. O., and Gulick, P. J. 2011. Heterotrimeric G $\alpha$ subunit from wheat (Triticum aestivum), GA3, interacts with the calcium-binding protein, Clo3, and the phosphoinositide-specific phospholipase C, PI-PLC1. Plant Mol. Biol. $77: 145-158$. 
28. Kiba, A., Nishihara, M., Nakatsuka, T., and Yamamura, S. 2007. Pathogenesis-related protein 1 homologue is an antifungal protein in Wasabia japonica leaves and confers resistance to Botrytis cinerea in transgenic tobacco. Plant Biotechnol. 24:247-253.

29. Kirubakaran, I. S., Begum, S. M., Ulaganathan, K., and Sakthivel, N. 2008. Characterization of a new antifungal lipid transfer protein from wheat. Plant Physiol. Biochem. 46:918-927.

30. Kohler, A., Schwindling, S., and Conrath, U. 2002. Benzothiadiazole induced priming for potentiated responses to pathogen infection, wounding, and infiltration of water into leaves requires the NPRI/NIM1 gene in Arabidopsis. Plant Physiol. 128:1046-1056.

31. La Camera, S., Gouzerh, G., Dhondt, S., Hoffmann, L., Fritig, B, Legrand, M., and Heitz, T. 2004. Metabolic reprogramming in plant innate immunity: The contributions of phenylpropanoid and oxylipin pathways. Immunol. Rev. 198:267-284.

32. Lane, B. G. 2002. Oxalate, germins, and higher-plant pathogens. IUBMB Life 53:67-75.

33. Liu, X., Williams, C. E., Nemacheck, J. A., Wang, H., Subramanyam, S., Zheng, C., and Chen, M. S. 2010. Reactive oxygen species are involved in plant defense against gall midge. Plant Physiol. 152:985-999.

34. Loeffler, C., Berger, S., Guy, A., Durand, T, Bringmann, G., Dreyer, M., von Rad, U,. Durner, J., and Mueller, M. J. 2005. B1-phytoprostanes trigger plant defense and detoxification responses. Plant Physiol. 137:328-340.

35. Lowry, O. H., Rosebrough, N. J., Fan A. L., and Randall, R. I. 1951. Protein measurement with the folin phenol reagent. J. Biol. Chem. 193:265-275.

36. Lu, Z. X., Gaudet, B., Puchalski, B., Despins, T., Frick, M., and Laroche, A. 2006. Inducers of resistance reduce common bunt infection in wheat seedlings while differentially regulating defence-gene expression. Physiol. Mol. Plant Pathol. 67:138-148.

37. Magnin-Robert, M., Trotel-Aziz, P., Quantinet, D., Biagianti, S., and Aziz, A. 2007. Biological control of Botrytis cinerea by selected grapevine-associated bacteria and stimulation of chitinase and $\beta-1,3$ glucanase activities under field conditions. Eur. J. Plant Pathol. 118:43-57.

38. Merzendorfer, H., and Zimoch, L. 2003. Chitin metabolism in insects: Structure, function and regulation of chitin synthases and chitinases. J. Exp. Biol. 206:4393-4412.

39. Moghaddam, M. R. B., and Van den Ende, W. 2012. Sugars and plant innate immunity. J. Exp. Bot. 63:3989-3998.

40. Molina, A., Görlach, J., Volrath, S., and Ryals, J. 1999. Wheat genes encoding two types of PR-1 proteins are pathogen inducible, but do not respond to activators of systemic acquired resistance. Mol. Plant-Microbe Interact. 12:53-58

41. Muchembled, J., Lounes-Hadj Sahraoui, A., Grandmoujin-Ferjani, A., and Sancholle, M. 2006. Changes in lipid composition of Blumeria graminis f. sp. tritici conidia produced on wheat leaves treated with heptanoyl salicylic acid. Phytochemistry 67:1104-1109.

42. Niderman, T., Genetet, I., Bruyère, T., Gees, R., Stintzi, A., Legrand, M., Fritig, B., and Mösinger, E. 1995. Isolation and characterization of three 14-kilodalton proteins of tomato and of a basic PR-1 of tobacco with inhibitory activity against Phytophthora infestans. Plant Physiol. 108:17-27.

43. Paul, M. J., Primavesi, L. F., Jhurreea, D., and Zhang, Y. 2008. Trehalose metabolism and signaling. Annu. Rev. Plant Biol. 59:417-441.

44. Perazzolli, M., Dagostin, S., Ferrari, A., Elad, Y., and Pertot, I. 2008. Induction of systemic resistance against Plasmopara viticola in grapevine by Trichoderma harzianum $\mathrm{T} 39$ and benzothiadiazole. Biol. Control 47:228-234.

45. Pfaffl, M. W., Horgan, G. W., and Dempfle, L. 2002. Relative expression software tool (RESTC) for group-wise comparison and statistical analysis of relative expression results in real-time PCR. Nucleic Acids Res. 30:e36.

46. Randoux, B., Renard D., Nowak, E., Sanssené, J., Courtois, J., Durand, R., and Reignault, P. 2006. Inhibition of Blumeria graminis f. sp. tritici germination and partial enhancement of wheat defenses by Milsana. Phytopathology 96:1278-1286.
47. Randoux, B., Renard-Merlier, D., Mulard, G., Rossard, S., Duyme, F. Sanssené, J., Courtois, J., Durand, R., and Reignault, P. 2010. Distinct defenses induced in wheat against powdery mildew by acetylated and nonacetylated oligogalacturonides. Phytopathology 100:1352-1363.

48. Rausher, M., Ádám, A. L., Wirtz, S., Guggenheim, R., Mendgen, K., and Deising, H. B. 1999. PR-1 protein inhibits the differentiation of rust infection hyphae in leaves of acquired resistant broad bean. Plant J. 19:625-633.

49. Reignault, P., Cogan, A., Muchembled, J., Lounes-Hadj Sahraoui, A., Durand, R., and Sancholle, M. 2001. Trehalose induces resistance to powdery mildew in wheat. New Phytol. 149:519-529.

50. Renard-Merlier, D., Randoux, B., Nowak, E., Farcy, F., Durand, R., and Reignault, P. 2007. Iodus 40, salicylic acid, heptanoyl salicylic acid and trehalose exhibit different efficacies and defence targets during a wheat/powdery mildew interaction. Phytochemistry 68:1156-1164.

51. Riechers, D. E., Yang, K., Irzyk, G. P., Jones, S. S., and Fuerst, E. P. 1996. Variability of glutathione S-transferase levels and dimethenamid tolerance in safener-treated wheat and wheat relatives. Pestic. Biochem. Physiol. 56:88-101.

52. Rolland, F., Moore, B., and Sheen, J. 2002. Sugar sensing and signaling in plants. Plant Cell S185-S205.

53. Sadka, A., DeWald, D. B., May, G. D., Park, W. D., and Mullet, J. E. 1994. Phosphate modulates transcription of soybean $V s p B$ and other sugar-inducible genes. Plant Cell 6:737-749.

54. Shetty, N. P., Jensen, J. D., Knudsen, A., Finnie, C., Geshi, N., Blennow, A., Collinge, D. B., and Jørgensen, H. J. L. 2009. Effects of $\beta$-1,3-glucan from Septoria tritici on structural defence responses in wheat. J. Exp. Bot. 60:4287-4300

55. Singh, V., Louis, J., Ayre, B. G., Reese, J. C., and Shah, J. 2011. Trehalsoe phosphate synthase11-dependent trehalose metabolism promotes Arabidopsis thaliana defense against the phloem-feeding insect Myzus persicae. Plant J. 67:94-104.

56. Streeter, J. G., and Gomez, M. L. 2006. Three enzymes for trehalose synthesis in Bradyrhizobium cultured bacteria and in bacteroids from soybean nodules. Appl. Environ. Microbiol. 72:4250-4255.

57. Sugiura, M., Yamamura, H., Hirano, K., Sasaki, M., Morikawa, M., and Tsuboi, M. 1979. Purification and properties of oxalate oxidase from barley seedlings. Chem. Pharm. Bull. 27:2003-2007.

58. Sun, J. Y., Gaudet, D., Lu, Z. X., Frick, M., Puchalski, B., and Laroche, A. 2008. Characterization and antifungal properties of wheat nonspecific lipid transfer proteins. Mol. Plant-Microbe Interact. 21:346-360.

59. Testerink, C., and Munnik, T. 2005. Phosphatidic acid: A multifunctional stress signaling lipid in plants. Trends Plant Sci. 10:368-375.

60. Thole, J. M., and Nielsen, E. 2008. Phosphoinositides in plants: Novel functions in membrane trafficking. Curr. Opin. Plant Biol. 11:620-631.

61. Thulke, O., and Conrath, U. 1998. Salicylic acid has a dual role in the activation of defence related genes in parsley. Plant J. 14:35-42.

62. Todd, J. F., Paliyath, G., and Thompson, J. E. 1990. Characteristics of a membrane-associated lipoxygenase in tomato fruit. Plant Physiol. 94:1225-1232.

63. Ton, J., Jakab, G., Toquin, V., Flors, V., Iavicoli, A., Maeder, M. N., Metraux, J. P., and Mauch-Mani, B. 2005. Dissecting the $\beta$-aminobutyric acid-induced priming phenomenon in Arabidopsis. Plant Cell 17:987-999.

64. Vossen, J. H., Abd-El-Haliem, A., Fradin, E. F., van den Berg, G. C., Ekengren, S. K., Meijer, H. J., Seifi, A., Bai, Y., ten Have, A., Munnik, T., Thomma, B. P., and Joosten, M. H. 2010. Identification of tomato phosphatidylinositol-specific phospholipase-C (PI-PLC) family members and the role of PLC4 and PLC6 in HR and disease resistance. Plant J. 62:224-239.

65. Wingler, A., Delatte, T., O'Hara, L. E., Primavesi, F., Jhurreea, D., Paul, M. J., and Schluepmann, H. 2012. Trehalose 6-phosphate is required for the onset of leaf senescence associated with high carbon availability. Plant Physiol. 158:1241-1251.

66. Wirth, S. J., and Wolf, G. A. 1992. Micro-plate colourimetric assay for endo-acting cellulase, xylanase, chitinase, $\beta$-1,3-glucanase and amylase extracted from forest soil horizons. Soil Biol. Biochem. 24:511-519. 